\title{
Light Absorption in Coralline Algae (Rhodophyta): A Morphological and Functional Approach to Understanding Species Distribution in a Coral Reef Lagoon
}

\author{
Román M. Vásquez-Elizondo and Susana Enríquez * \\ Laboratorio de Fotobiología, Unidad de Sistemas Arrecifales Puerto Morelos, Instituto de Ciencias del Mar y Limnología, \\ Universidad Nacional Autónoma de Mexico, Cancún, Mexico
}

\section{OPEN ACCESS}

Edited by:

Daniel Wangpraseurt, University of Cambridge, United Kingdom

Reviewed by:

Charles Alan Jacoby, St. Johns River Water Management

District, United States Hollie Putnam,

Hawai'i Institute of Marine Biology, United States

*Correspondence:

Susana Enríquez enriquez@cmarl.unam.mx; susana.enriquezdominguez@gmail.com

Specialty section:

This article was submitted to

Coral Reef Research

a section of the journal

Frontiers in Marine Science

Received: 31 March 2017

Accepted: 30 August 2017

Published: 14 September 2017

Citation:

Vásquez-Elizondo RM and Enríquez S

(2017) Light Absorption in Coralline Algae (Rhodophyta): A Morphological and Functional Approach to Understanding Species Distribution in a Coral Reef Lagoon.

Front. Mar. Sci. 4:297.

doi: 10.3389/fmars.2017.00297
Red coralline algae are a cosmopolitan group with the ability to precipitate $\mathrm{CaCO}_{3}$ within the walls of their vegetative cells. The resultant carbonate structure is key for explaining their ecological success, as it provides protection against herbivores and resistance to water motion. However, its potential contribution to enhance thallus light absorption efficiency through multiple light scattering on algal skeleton, similar to the effect documented for scleractinian corals, has not been yet investigated. Here, we initiate this analysis, characterizing thallus optical properties of three coralline species, which differed in pigment content and thallus mass area (TMA, $\mathrm{gDW} \mathrm{m}^{-2}$ ). The three species, the rhodolith Neogoniolithon sp., the crustose coralline alga (CCA), Lithothamnion sp., and the articulated alga Amphiroa tribulus, represent the more distinctive coralline growth-forms and are able to colonize contrasting light environments in Caribbean coral reefs. The thicker thalli of the rhodoliths were the most efficient light collectors, as evidenced by their higher pigment absorption efficiency $\left(\mathrm{a}^{*} \mathrm{Chla} ; \mathrm{m}^{2} \mathrm{mgChla}^{-1}\right)$ and photosynthetic rates per unit area. This could explain rhodolith success in oligotrophic, highly illuminated reef environments. In contrast, the thinner thalli of the CCA, a low-light specialist, showed the highest metabolic rates normalized to mass and the highest light absorption efficiencies per unit mass $\left(a^{*}{ }_{m} ; \mathrm{m}^{2} \mathrm{gdw}^{-1}\right)$. Therefore, the ecological success of the CCA in cryptic habitats within the reef cannot be explained only by its low-light physiology, but also by its capacity to reduce the structural costs of their thalli, and thus of its new growth. Lastly, the ecological success of Amphiroa tribulus, which displayed intermediate values for the efficiency of light absorption, metabolic rates and TMA, was explained by its ability to construct the largest light collectors (algal canopies) thanks to the presence of flexible, non-calcified segments (genicula). This ability enables enhanced photosynthetic and carbonate production at the organism/canopy level. The resulting fragile canopy survives best within the protection provided by colonies of the lettuce coral Agaricia agaricites. In conclusion, our study demonstrates the utility of optical traits as powerful tools to investigate differences in the competitive abilities, abundances and niche distribution among algal species and/or growth-forms.

Keywords: optical traits, photosynthesis, niche differentiation, rhodoliths, CCA, articulated alga, coral reefs, Amphiroa tribulus 


\section{INTRODUCTION}

Coralline algae are a diverse group of red macroalgae with the ability to calcify within the walls of their vegetative cells (Johansen, 1981). This broad taxonomic group is present in virtually every coastal ecosystem, from highly illuminated, intertidal regions to extremely light-limited habitats like rock crevices or depths of $250 \mathrm{~m}$ (Johansen, 1981; Littler et al., 1985; Payri et al., 2001; Burdett et al., 2014). The ecological significance of coralline algae varies from playing a fundamental role as ecosystem engineers of highly diverse communities (Foster, 2001; Steller et al., 2003) to being the preferred substrate for settlement of invertebrate larvae (Heyward and Negri, 1999; Williams et al., 2008). In certain ecosystems, corallines are the main contributors to carbon budgets (Chisholm, 2003; Martin et al., 2006; Bensoussan and Gattuso, 2007). On coral reefs, corallines are fundamental for cementing the primary reef framework and maintain habitat diversity (Littler, 1972; Littler and Doty, 1975; Adey, 1998; Perry and Hepburn, 2008; Perry et al., 2008). Carbonate skeletons are considered responsible for the distribution and abundance of many species (Steneck, 1986; Vadas and Steneck, 1988; Steneck et al., 1991; Steneck and Dethier, 1994; Steller and Foster, 1995; Foster, 2001), and ultimately for the ecological success of coralline algae in marine habitats, as they play fundamental roles providing protection against herbivores and resistance to water motion.

The ability of coralline algae to colonize contrasting marine environments (Algarra and Niell, 1987; Häder et al., 1997; Payri et al., 2001; Schubert and García-Mendoza, 2008; Enríquez et al., 2009; Vásquez-Elizondo and Enríquez, 2016) relies on multiple physiological and structural adaptations. Among them, the optical properties of thalli may play a central role, as they are fundamental regulators of algal photosynthetic responses by controlling the entrance of solar energy. Changes in the efficiency of light absorption could help to elucidate the differential ability of organisms to acclimate or adapt to differing light regimes and the consequences of these responses on coralline photosynthetic performance. Unfortunately, little is known about the optical properties of coralline algae. The technical difficulties of performing optical measurements on highly dispersive structures, have strongly limited this area of research (Vásquez-Elizondo et al., 2017). Several studies have characterized the optical properties of multicellular photosynthetic tissues in aquatic organisms, such as marine macroalgae (Ramus, 1978; Frost-Christensen and Sand-Jensen, 1992; Enríquez et al., 1994, 2009; Mercado et al., 1996; Schubert et al., 2011); seagrasses and freshwater angiosperms (e.g., Enríquez et al., 1992; Frost-Christensen and Sand-Jensen, 1992; Olesen et al., 2002; Enríquez and Sand-Jensen, 2003; Enríquez, 2005; Cayabyab and Enríquez, 2007; Durako, 2007), and scleractinian corals (Shibata, 1969; Enríquez et al., 2005; Rodríguez-Román et al., 2006; Wangpraseurt et al., 2017). All these studies have documented large within and among species variation in optical properties of multicellular photosynthetic structures. Some of them documented common trends among species related to basic structural traits, such as pigment content, tissue thickness and specific mass area (Ramus et al., 1976a,b;
Ramus, 1978, 1990; Enríquez et al., 1992, 1994, 2005; Olesen et al., 2002; Enríquez and Sand-Jensen, 2003; Enríquez, 2005). Small structural modifications in key photosynthetic structures may lead to significant changes in optical properties of tissues, with subsequent implications for photosynthetic performance. Many aquatic organisms reduce the optical absorption crosssections of their multicellular photosynthetic structures (i.e., thalli/leaves) at increasing light levels and become thinner when light limits their growth (Lüning and Dring, 1985; Markager and Sand-Jensen, 1992; Enríquez and Sand-Jensen, 2003). These photoacclimatory responses are similar to the widely documented response of unicells (e.g., Raven and Geider, 2003), but they contrast with descriptions for terrestrial leaves, which generally exhibit little variation in light absorption and no clear pattern of change in pigment content with irradiance (i.e., Björkman, 1981). Scattering of light within terrestrial leaves produces significant enhancements in their internal light field, even above external incident irradiance levels (Vogelmann and Björn, 1984; Vogelmann et al., 1996). This phenomenon, which strongly depends on the anatomical characteristics of the leaf and the presence/absence of light-reflecting structures (Vogelmann et al., 1988, 1996), is known as multiple light scattering. Multiple scattering of light has important consequences for leaf photosynthetic performance (Vogelmann et al., 1989, 1996) and strongly reduces the role of pigment content as a fundamental control of tissue light absorption. Multiple scattering of light on carbonate skeletons of corals has been demonstrated to enhance the ability of symbiotic algae to collect light in hospite, despite the fact that pigment contents of symbiotic corals are lower than leaves of land plants (Enríquez et al., 2005). Furthermore, the ecological and evolutionary success of symbiotic Scleractinia in oligotrophic, tropical environments has been attributed to the extraordinary light absorption properties of the host-symbiontskeleton unit (Enríquez et al., 2005, 2017).

In coralline algae, however, the capacity of carbonate skeleton to enhance light absorption and photosynthetic performance remains unknown (see Payri et al., 2001; Burdett et al., 2014). Recently, Vásquez-Elizondo and Enríquez (2016) documented significant differences in the light absorption properties of three coralline species, before and after exposing the experimental organisms to heat-stress. These authors attributed the differences in coralline sensibility to heat-stress to differing abilities to withstand light-stress induced by elevated temperature. Similar exacerbations of light-stress have been documented for symbiotic scleractinian corals exposed to heat-stress (Warner et al., 1996; Iglesias-Prieto and Trench, 1997). Interestingly, corals share with coralline algae similar sensitivity to ocean warming and acidification, two major global threats that affect marine habitats (Hoegh-Guldberg et al., 2007; McCoy and Kamenos, 2015; Vásquez-Elizondo and Enríquez, 2016).

In the present study we analyzed the optical properties of the same three coralline species examined by Vásquez-Elizondo and Enríquez (2016), as model organisms to investigate the association between optical traits and structural descriptors, such as pigment content and thallus mass area: the rhodolith forming species Neogoniolithon sp.; the articulated algae Amphiroa tribulus; and the low-light incrusting alga-CCA Lithothamnion 
sp. The optical traits characterize were: (i) absorptance (A), defined as the fraction of incident light absorbed by thallus photosynthetic pigments, which describes the capacity of light absorption by algal thalli to sustain photosynthetic activity; and (ii) two descriptors for light absorption efficiency, pigmentspecific absorption coefficient $\left(a_{\text {pigm }}^{*} \mathrm{~m}^{2} \mathrm{mg} \mathrm{pigm}^{-1}\right)$ and mass-specific absorption coefficient $\left(a^{*}{ }_{\mathrm{M}}, \mathrm{m}^{2} \mathrm{~g} \mathrm{DW}^{-1}\right)$. The first, $a^{*}$ pigm, describes pigment efficiency of the light collector (algal thalli), and the second, $a^{*}{ }_{\mathrm{M}}$, describes light absorption efficiency of thallus structural mass. Both descriptors have been previously determined for the leaves of an amphibious plant, Mentha aquatica (Enríquez and Sand-Jensen, 2003) and for the leaves of the seagrass Thalassia testudinum (Enríquez, 2005). The analysis of $a^{*}{ }_{\mathrm{M}}$ follows previous suggestions by Falkowski et al. (1985), Ramus (1990), and Enríquez et al. (1994).

\section{MATERIALS AND METHODS}

\section{Sample Collection and Experimental Manipulation of Organisms}

Samples of three species (Figure 1) were collected from the reef lagoon of Puerto Morelos (Mexican Caribbean, $20^{\circ} 51^{\prime} \mathrm{N}$, $86^{\circ} 55^{\prime} \mathrm{W}$ ) between 2011 and 2013. Specimens of the rhodolith forming species Neogoniolithon sp. were collected at $3 \mathrm{~m}$ depth by snorkeling within the seagrass bed. Samples of the articulated alga Amphiroa tribulus and the crustose coralline (CCA) Lithothamnion sp. were collected by SCUBA diving at a depth of 5-6m within the back-reef coral community. The three species inhabit contrasting light environments, and show contrasting photobiology and growth-forms (VásquezElizondo and Enríquez, 2016). Neogoniolithon sp. colonizes mobile substrates (sand) inside open seagrass beds in the highly illuminated, shallow reef lagoon, and exhibits a highlight acclimatory response (Vásquez-Elizondo and Enríquez,
2016). The articulated and CCA algae colonize less illuminated habitats within the reef community and show contrasting photobiology. The CCA Lithothamnion sp. is a low light specialist, which grows underneath or adjacent to colonies of Orbicella faveolata and O. annularis, in cryptic environments within the reef that do not receive direct solar radiation (VásquezElizondo and Enríquez, 2016). The articulated alga, Amphiroa tribulus, grows within colonies of the lettuce-leaf coral Agaricia agaricites (Figure S1 in Supporting Information, SI) and exhibits contrasting pigmentation between both sides of its thalli. The irradiance reaching each of the sites was estimated about 37\% of surface irradiance (Es) for the back-reef at 5-6 $\mathrm{m}$ depth, and $47 \%$ of Es for the open seagrass bed (calculated from in situ measurements of water column attenuation coefficients, $\mathrm{K}_{\mathrm{d}}=$ $0.198 \mathrm{~m}^{-1}$, similar to values reported by Enríquez and PantojaReyes, 2005). After collection, samples were transported in black plastic bags to the outdoor tank facilities of the Universidad Nacional Autónoma de México (UNAM) at the Unidad Académica de Sistemas Arrecifales (UASA) in Puerto Morelos (Quintana Roo, Mexico). This approach avoids degradation of pigments and damage to thalli due to exposure to full solar radiation. The outdoor facilities consist of 48 experimental tanks of 30-L, connected to eight 1,000-L header tanks. Each header tank was supplied with constant seawater from the reef lagoon, which then supplied the experimental tanks. Water temperature in the tanks was controlled using commercial aquarium heaters (Process, Technology, USA). Light conditions were simulated to match the particular habitat of each of the species using neutral screens: attenuation of 53\% Es for the rhodoliths; $75 \%$ Es for the articulated alga; and about $\approx 98 \%$ Es for the CCA, as this species inhabits an extremely low-light environment (cf., Vásquez-Elizondo and Enríquez, 2016). Most experimental determinations were made $2-3$ days after collection, and all were completed within a week. Prior to experimental determinations, branches of the rhodolith and articulated algae, and $2-3 \mathrm{~cm}^{2}$
A

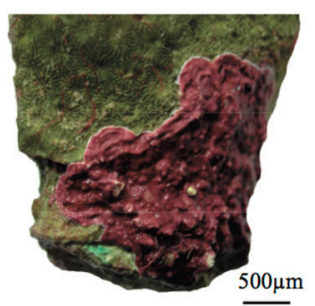

D

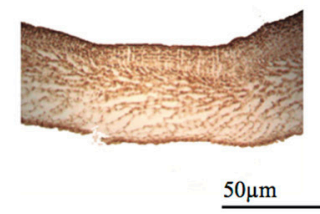

B

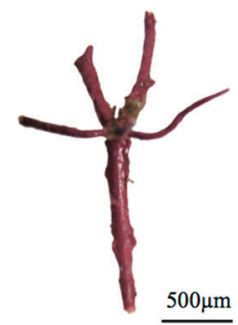

E

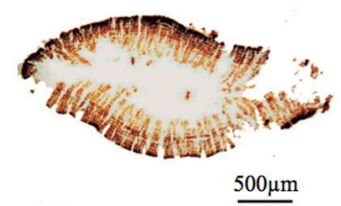

C

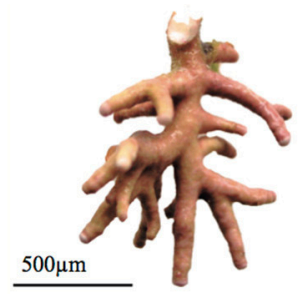

$\mathbf{F}$

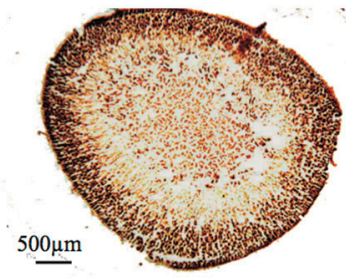

FIGURE 1 | Images of the three coralline algae (Rhodophyta) characterized in this study. (A) The crustose coralline alga (CCA), Lithothamnion sp. growing on some dead coral skeleton of the genus Orbicella. (B) The articulated alga Amphiroa tribulus. (C) The rhodolith forming species belonging to the genus Neogoniolithon sp. (D-F) show a microscopic cross section of their respective thalli. 
segments of the CCA were cleaned gently to remove epiphytes (mainly fleshy algae) and minimize potential interferences during optical characterizations. Two optical determinations were performed for each thallus of the articulated alga, as this species presented a heterogeneous anatomy with two distinct pigmentations on the opposite sides of their branches. The optical properties of each side were characterized, referred as to the highly-pigmented (HP) upper side, and lesser-pigmented (LP) lower side. CCA segments were detached from the substratum before optical characterization.

\section{Thallus Structural Descriptions}

Pigment content was measured spectrophotometrically on the same samples used for light absorption determinations. Fragments of coralline thalli were manually homogenized before pigment extraction. Phycobilliprotein extraction (phycoerythrin PE, phycocyanin PC, and allophycocyanin APC) was performed adding a phosphate potassium buffer $(0.1 \mathrm{M}, \mathrm{pH}$ 6.8) to the homogenized sample. Pigment extractions were analyzed in a conventional spectrophotometer (Elyptica, Ensenada, Mexico) after centrifuging samples maintained in darkness at $4{ }^{\circ} \mathrm{C}$ for $2 \mathrm{~h}$. The residual carbonate pellet was re-suspended in $80 \%$ acetone for chlorophyll $a$ extraction. Samples were maintained overnight in darkness, at $4^{\circ} \mathrm{C}$. Phycobilliprotein and chlorophyll $a$ contents were calculated according to the equations of, respectively, Kursar et al. (1983) and Lichtenthaler and Wellburn (1983).

Thallus mass area (TMA, $\mathrm{g} \mathrm{cm}^{-2}$ ) was calculated as the ratio between thallus dry mass and its projected area. This parameter is the inverse of the specific leaf area (SLA, $\left.\mathrm{cm}^{2} \mathrm{gDW}^{-1}\right)$, a common descriptor in plant ecology (e.g., Garnier et al., 1997; Poorter and De Jong, 1999; Evans and Poorter, 2001), and equivalent to leaf mass area $(1 /$ SLA $=$ LMA; i.e., Witkowski and Lamont, 1991; de la Riva et al., 2016). Dry weight was determined by drying the samples for $48 \mathrm{~h}$ at $60^{\circ} \mathrm{C}$. These measurements allowed description of an association for each species between thallus fresh (blotting dry) and dry weight $\left(R^{2}>0.95, P<\right.$ $0.05, n=7)$. Subsequent dry weight estimations were derived from direct fresh weight measurements. We also determined thallus thickness $(\mathrm{mm})$ from indirect estimations, using its linear association with TMA previously described [thallus thickness $(\mathrm{mm})=5.96^{*} \mathrm{TMA}+0.033 ; R^{2}=0.90 ; P<0.001 ; n=32 ; S E$ $=0.158]$. Ash-free dry weight (organic content) was estimated by decalcification of dried thalli of known weight with $\mathrm{HCl}(10 \%$ $\mathrm{v}: \mathrm{v})$. Calcium carbonate content per total dry mass $\left(\% \mathrm{CaCO}_{3}\right)$ was further determined by subtracting the organic dry weight, according to Steller et al. (2007). The surface area of rhodoliths and the articulated alga was measured using digital images and IMAGE ${ }^{\mathrm{TM}}$ software. For CCA segments, the projected area or cross-section area was obtained by covering the alga with aluminum foil, weighing the aluminum piece and comparing it to a reference of known area and weight (aluminum foil technique, Marsh, 1970). Special care was taken to minimize overlap. Pigment content values were normalized to surface area and dry mass for estimations of two descriptors: thallus pigment density $\left(\mathrm{mg} \mathrm{m}^{-2}\right)$, and thallus pigment content $\left(\mathrm{mg} \mathrm{g} \mathrm{DW}^{-1}\right)$.

Finally, for the description of the three-dimensional (3D-) coralline morphology (algal canopy), we calculated the totalone sided surface area referenced by its vertical projection (no units or $\left.\mathrm{m}^{2} \mathrm{~m}^{-2}\right)$. This calculation is equivalent to the leaf area index (LAI; Watson, 1947), which is a common descriptor for terrestrial plant canopies. Complete individuals of each species were photographed from a vertical perspective using a white bottom plate, and the projected area was obtained using IMAGE ${ }^{\mathrm{TM}}$ software. Subsequently, branches were manually separated to estimate the total one-sided area of the thalli, following the protocol described previously. Coralline LAI was calculated as the ratio between total surface area of the organisms against its projected ground area.

\section{Optical Determinations}

Reflectance spectra $(R)$ were performed according to VásquezElizondo et al. (2017), using a miniature Ocean Optics USB2000 spectroradiometer (Ocean Optics, Inc., Dunedin, Fl, USA). Reflected light was collected with a $2 \mathrm{~mm}$ fiber optic placed over the thallus surface at an angle of $45^{\circ}$ and a distance of 3$5 \mathrm{~mm}$. Algal segments were placed in a black container filled with seawater, and we prevented the fiber optic from shading the sample. The spectral variability collected between 400 and 750 $\mathrm{nm}$, was registered by the spectroradiometer using the software SpectraSuite $^{\mathrm{R}}$ (Ocean Optics, Inc., Fl, USA). Reflectance was expressed as the ratio between radiance measurements from the surface of pigmented thalli relative to radiance reflected by a white reference (Teflon). Homogeneous diffuse illumination was provided from a semi-sphere coated with barium oxide $(\mathrm{BaO})$, which was illuminated from below using different commercial light sources in order to fulfill the PAR range illumination (400-700 nm). This semi-sphere was placed above the black container at approximately $25 \mathrm{~cm}$ from the algal fragments. Reflectance spectra of pigmented fragments were corrected by normalizing them to the reflectance of nearly identical but bleached fragments. All determinations showed reflectance values above $0.94\left(R_{725}-750 \mathrm{~nm}=94 \%\right.$ light reflected $)$ in the range between 725 and $750 \mathrm{~nm}$, which implies that the magnitude of residual light scattering was sufficiently low, around 6\%.

Determinations of light transmission (Absorbance, $D$ ) were performed using a spectrophotometer AMINCO DW2 (USA) controlled by an OLIS data collection system, equipped with an opal-glass in front of the detector (Shibata, 1959). Thallus fragments were mounted in a $3 \mathrm{ml}$ cuvette, filled with filtered seawater. Algal thalli were held against the wall of the cuvette using a holder specifically developed to avoid misplacement during determinations (Enríquez, 2005). Measurements were performed between 400 and $750 \mathrm{~nm}$ at intervals of $1 \mathrm{~nm}$. Attenuance (apparent absorbance) was corrected for residual scattering by subtracting absorbance at $750 \mathrm{~nm}$. All spectra produced absorbance $(\mathrm{D})$ values below 0.1 for the range 725-750 $\mathrm{nm}\left(\mathrm{D}_{725-750}\right)$. Naturally bleached samples of coralline algae were used as blanks for subtraction of non-photosynthetic absorption (Enríquez, 2005; Vásquez-Elizondo et al., 2017).

We calculated the optical descriptors as follows:

(1) thallus absorptance (A) was calculated as:

$$
\mathrm{A}(\lambda)=1-10^{-\mathrm{D}(\lambda)}-\mathrm{R}(\lambda)
$$

where $10^{-D(\lambda)}, D(\lambda)$ and $R(\lambda)$ denote, respectively, transmittance $(\mathrm{T})$, absorbance $(\mathrm{D})$, and reflectance $(\mathrm{R})$ at a particular 
wavelength $(\lambda)$. Absorptance was estimated for the average PAR range $\left(\mathrm{A}_{\mathrm{PAR}}\right)$ and for the chlorophyll $a(\mathrm{Chl} a)$ peak at $680 \mathrm{~nm}$ $\left(\mathrm{A}_{\mathrm{Chl} a}\right)$. Pigmented branches of the rhodolith Neogoniolithon sp. that are about $1.4 \pm 0.21 \mathrm{~mm}$ thick transmit on average $1.2 \% \pm 0.21(n=6)$ of the incident light (Vásquez-Elizondo et al., 2017). Therefore, we considered transmission through rhodolith branches to be 0 for samples thicker than $1.4 \mathrm{~mm}$, and that absorptance could be derived directly from reflectance data as proposed by Enríquez et al. (2005) and confirmed by Vásquez-Elizondo et al. (2017). Absorptance for these samples was calculated as:

$$
\mathrm{A}(\lambda)=1-\mathrm{R}(\lambda)
$$

(2) the efficiency of light collection was quantified using two parameters, pigment specific absorption coefficient $\left(a^{*}\right.$ pigm in $\mathrm{m}^{2}$ $\mathrm{mg} \mathrm{pigm}^{-1}$ ) calculated as:

$$
\mathrm{a}^{*}{ }_{\text {pigm }}=(\mathrm{D} / \rho) \ln 10
$$

and mass specific absorption coefficient $\left(a^{*}{ }_{\mathrm{M}}\right.$, in $\left.\mathrm{m}^{2} \mathrm{gDW}^{-1}\right)$ calculated as:

$$
\mathrm{a}^{*}{ }_{\mathrm{M}}=(\mathrm{D} / \mathrm{TMA}) \ln 10
$$

where $D$ is absorbance, $\rho$ is pigment cross section in $\mathrm{mg} \mathrm{m}^{-2}$, and TMA is thallus mass area. $a^{*}$ pigm was calculated for the PAR range $\left(a^{*}\right.$ Pigm $)$ and for the Chl $a$ peak at $680 \mathrm{~nm}\left(a^{*} \mathrm{Chl} a\right)$, using, respectively, total pigment and Chla density values. Similarly, $a^{*}$ M was estimated for the PAR region ( $a^{*}$ MPAR $)$ and for the Chla peak at $680 \mathrm{~nm}\left(a^{*}{ }_{\mathrm{M} 680}\right)$.

Absorbance for thalli of rhodoliths was estimated from reflectance measurements using the transformation $D(\lambda)=\log [1 / R(\lambda)]$ proposed by Shibata (1969) and Enríquez et al. (2005). Optical determinations on rhodoliths only required one measurement (reflectance), whereas the other two species needed two optical measurements (transmittance and reflectance) to estimate absorptance. This explains why the number of determinations for rhodoliths was higher than for the other two species.

\section{Photosynthetic Determinations}

The physiological data used in this comparison were derived from Vásquez-Elizondo and Enríquez (2016), who characterized photosynthetic rates of samples exposed to control conditions (summer conditions of $30^{\circ} \mathrm{C}$ and ambient $\mathrm{pH}$ ) and three experimental treatments: heat-stress $\left(32^{\circ} \mathrm{C}\right)$; reduced $\mathrm{pH}(7.9)$ and combined heat-stress and reduced $\mathrm{pH}\left(32^{\circ} \mathrm{C}\right.$ and $\mathrm{pH}$ $=7.9$ ), at the UNAM mesocosms facilities. Experimental organisms were collected in August 2013 from the same sites described previously of the reef lagoon of Puerto Morelos, and expressed, thus, the summer "phenotype" for the three coralline populations. Photosynthetic rates were estimated polarographically using oxygen Clark type electrodes, in closed chambers (Hansatech, Nortfolk, UK) connected to a circulating bath with temperature control (RTE-100/RTE 101LP; Neslab Instruments Inc., Portsmouth, NH, USA). Samples were incubated for $45 \mathrm{~min}$ under saturating irradiances
(>Ek) according to the particular photobiology of each species, which was previously characterized by VásquezElizondo and Enríquez (2016), through the description of the photosynthetic response to irradiance ( $P$ vs. E) curve. Post-illumination respiration $\left(\mathrm{R}_{\mathrm{L}}\right)$ was determined in darkness, right after $\mathrm{P}_{\max }$ incubations. $\mathrm{R}_{\mathrm{L}}$ allowed estimation of gross photosynthesis rates from knowledge of oxygen consumption at $\mathrm{P}_{\max }$. Maximum gross photosynthesis, $P_{\max }$, was normalized either per projected area $\left(\mu \mathrm{mol} \mathrm{O} \mathrm{Cm}^{-2} \mathrm{~h}^{-1}\right)$ or dry weight $\left(\mu \mathrm{mol} \mathrm{O} \mathrm{gDW}^{-1} \mathrm{~h}^{-1}\right.$ ). Photosynthesis data from Vásquez-Elizondo and Enríquez (2016) are available at https://search.datacite.org/works/10.1594/PANGAEA.860802 (doi: 10.1594/PANGAEA.860802).

\section{Photosynthetic Production Estimations}

Total photosynthetic production per individual was calculated by multiplying thallus photosynthetic rates per area by the estimated Leaf Area Index of each morphology. For comparison among coralline growth-forms, we assumed the simplest scenario using estimates of net photosynthetic production for $1 \mathrm{~h}$ at saturation irradiance $\left(\mathrm{P}_{\max }\right)$.

\section{Comparison of Optical Properties among Different Photosynthetic Structures}

Using data from the literature for pigment specific absorption normalized to chlorophyll a $\left(a^{*} \mathrm{Chl} a, \mathrm{~m}^{2} \mathrm{mg} \mathrm{Chl} a^{-1}\right)$, we compared these published values against the variability estimated for the three coralline species in our study. The aquatic photosynthetic structures considered in this comparison were $>30$ species from Atlantic and Mediterranean coastal habitats, mostly non-calcifying red algae, characterized by Enríquez et al. (1994); the amphibious aquatic angiorperm Mentha aquatica described by Enríquez and Sand-Jensen (2003); the seagrass Thalassia testudinum characterized by Enríquez (2005); and the scleractinian coral, Porites branerii documented by Enríquez et al. (2005). Data from Enríquez et al. (1994) were re-calculated from original $\mathrm{D}_{680}$ and Chla values, which allowed estimation of $a^{*} \mathrm{Chl} a$ according to Enríquez and Sand-Jensen (2003) and Enríquez (2005).

\section{Data Analyses}

One-way analysis of variance, ANOVA-test, was used to find differences among species in their structural and optical descriptors, after testing for normality and homoscedasticity assumptions. Pearson correlation coefficients ( $r$ ) were used to determine association of variation between log-log transformed, structural and optical descriptors. Least-squares (LS) regression analyses of log-log transformed data were used to describe the associations of variation according to the equation: $[\log \mathrm{Y}=\mathrm{a}+$ $\mathrm{b} \log \mathrm{X}]$, which allows description of the allometric function [Y $=\mathrm{aX}^{\mathrm{b}}$.

Analyses of covariance, ANCOVA tests, were also used to test for significant differences in the intercept or the slope of the linear LS-regression associations. For testing differences among species in the covariation between the capacity of light absorption (absorptance) and pigment density, we used an exponential model $\left[\mathrm{y}=A_{\max }{ }^{*}\left(1-\mathrm{e}^{-b * x}\right)\right]$, where $A_{\max }$ denotes 
maximum absorptance and $\mathrm{b}$ is the initial exponential rise of this association. All statistics were performed using the IBM-SPSS ${ }^{\mathrm{TM}}$ Statistics (Statistical Package for the Social Sciences).

\section{RESULTS}

The three coralline algae displayed significant differences in thallus structure and optical properties (Figures 1, 2, Table S1 in the supporting information, SI). The rhodolith, Neogoniolithon sp., had the thickest thalli, largest TMA and highest carbonate content, together with the lowest thallus pigmentation per unit area and dry weight (Figure 2, Table S1 in SI). In contrast, the CCA, Lithothamnion sp., had the thinnest thalli, lowest TMA and highest pigment content normalized to dry weight (Figures 2C,D). The highest pigment content per area (pigment density), however, was found in the articulated alga, Amphiroa tribulus (Figure 2A). Thallus thickness was positively correlated with TMA and negatively with thallus pigmentation (Table S2 in SI). Other relationships varied among species, with TMA being positively correlated with Chla per unit area for all three coralline species, and positively correlated with total pigmentation per area only for the rhodolith and CCA. No correlation was observed between TMA and thallus pigmentation per unit mass (Tables S2-4, SI).

Transmission absorption spectra showed the typical features of Rhodophyta, with an absorption band at $620-625 \mathrm{~nm}$ for PC; peaks at 490,545 , and $576 \mathrm{~nm}$ for PE; and at $650 \mathrm{~nm}$ for APC. The presence of Chla was evidenced at $430-434 \mathrm{~nm}$ and at its red peak at $680 \mathrm{~nm}$ (Figures 3A-C). This Chla red absorption peak masked PC and APC peaks, which were only seen for low-pigmented samples. Reflectance spectra showed opposite features: lower values in the absorption bands of the photosynthetic pigments (Figures 3D-F) and higher in the nonabsorbing PAR regions. When transforming reflectance spectra of the rhodolith branches into absorbance values following the equation $D(\lambda)=\log [1 / R(\lambda)]$, we observed in the newly calculated spectra similar absorption bands and peaks to those obtained directly through transmission measurements (Figure 3C).

The optical descriptors estimated from transmission and reflectance measurements showed significant differences among species (Figures 2G-L, Table S1, SI). A higher absorptance was found for the rhodolith Neogoniolithon sp., whereas the lowest was shown by the CCA Lithothamnion sp. (Figures 2G,H). A. tribulus thalli exhibit a more complex optical behavior with higher absorptance at the upper higher-pigmented side relative to the lower side (Figures 2G,H). Larger differences were observed for pigment- and mass-specific absorption coefficients (Figures 2I,L). Pigment specific coefficients, $a^{*}$ Pigm and $a^{*} \mathrm{Chl} a$, were three-fold higher for the rhodoliths relative to the values shown by the articulated alga and the CCA (Figures 2I,J, Table $\mathrm{S} 1, \mathrm{SI})$. In contrast, light absorption efficiency per mass, $a^{*}$ MPAR and $a^{*}{ }_{\mathrm{M} 680}$, were three-fold higher for the CCA than for the rhodoliths. Contrasting differences between both sides of $A$. tribulus thalli were also observed for these coefficients: the upper side showed similar values to the rhodoliths, whereas the lower side to the CCA (Figures 2K,L, Table S1 in SI).
All these optical parameters showed species-specific non-linear associations with coralline structural descriptors (Figures 4, 5; Tables 2, 3). Absorptance ( $\mathrm{A}_{\mathrm{PAR}}$ and $\mathrm{A}_{\mathrm{Chl} a}$ ) increased non-linearly as total pigmentation or Chla per area increased to a maximum value, $A_{\max }$ (Figures 4A,B, Table 1). The CCA Lithothamnion sp. showed the lowest $A_{\max }$ despite its high pigment content, while rhodoliths achieved $\mathrm{A}_{\max }$ at the lowest thallus pigmentation (Figures 4A,B, Table 1).

To better understand these differences, we analyzed the covariation between pigment absorption efficiency, $a^{*}$ Pigm or $a^{*} \mathrm{Chla}$, and pigment density. This analysis showed two strong, non-linear and negative associations, which highlighted significant differences among species for this common trend (Figures 4C,D; Tables 2, 3). The thick and low-pigmented thalli of the rhodolith Neogoniolithon sp. exhibited higher pigment absorption efficiency at low pigmentation than the thinner thalli of the other two species (Figures 4C,D; Table S1 in SI). Furthermore, small changes in pigmentation resulted in larger variations in $a^{*}$ Pigm and $a^{*} \mathrm{Chl} a$ for the rhodolith.

On the other hand, thallus pigmentation normalized to mass showed negative associations with $a^{*}$ Pigm and $a^{*}$ Chla but positive with mass specific absorption ( $a^{*}{ }_{\text {MPAR }}, a^{*}{ }_{M 680}$; Figures 4E,F; Tables S2-S4 in SI). These positive associations resulted in part from a negative colinearity between TMA and thallus pigmentation (Tables S2-S4 in SI). Specifically, we observed for TMA: (i) a positive effect on coralline absorptance ( $A_{P A R}$ and $\left.\mathrm{A}_{\mathrm{Chl} a}\right)$ and on pigment specific absorption ( $a^{*}$ Pigm and $a^{*} \mathrm{Chl} a$ ) (Figures 5A-D; Table 2); and (ii) a negative effect on the variation of mass specific absorption ( $a^{*}$ MPAR and $a^{*}$ M680; Figures 5E,F; Tables 2, 3). Interestingly, variation in TMA was able to explain $45-50 \%$ variability analyzed in coralline absorptance (Figures 5A,B; Table 2). However, such positive effect of TMA on enhancing light absorption capacity of coralline thalli was not observed for the intra-specific comparison. On the contrary, negative associations were found between TMA and $a^{*}$ Pigm, which were significant for rhodoliths and CCA thalli but not for the articulated alga (Tables 2, 3; Figures 5A-D).

In contrast to the large species-specific component observed for the associations of variation of pigment specific absorption $\left(a^{*}\right.$ Pigm and $\left.a^{*} \mathrm{Chl} a\right)$, mass specific absorption ( $\left.a^{*}{ }_{\text {MPAR }}, a^{*}{ }_{\text {M680 }}\right)$ showed a common trend for the three coralline species investigated (Figures 4, 5). We observed a single non-linear and negative association with TMA (Figures 5E,F, Tables 2, 3), which supports the interpretation that the simplest CCA coralline morphology can achieve the highest $\mathrm{a}^{*}{ }_{M}$ values thanks to its thin and highly pigmented thalli, whereas the thick and low pigmented thalli of the rhodolith constrain this morphotype to low $\mathrm{a}^{*}{ }_{\mathrm{M}}$ (Figures 5E,F). In addition, small changes in TMA result in large variation in $a^{*}$ MPAR and $a^{*}$ M680 for both, CCA and articulated alga, whereas the rhodolith exhibited the lowest $\mathrm{a}^{*} \mathrm{M}$ and the lowest variation for this optical descriptor.

To better understand the different contributions of TMA and thallus pigmentation to the variation of pigment and mass specific absorption, a multiple regression analysis was conducted. Two quantitative models enable description of this differential contribution: 

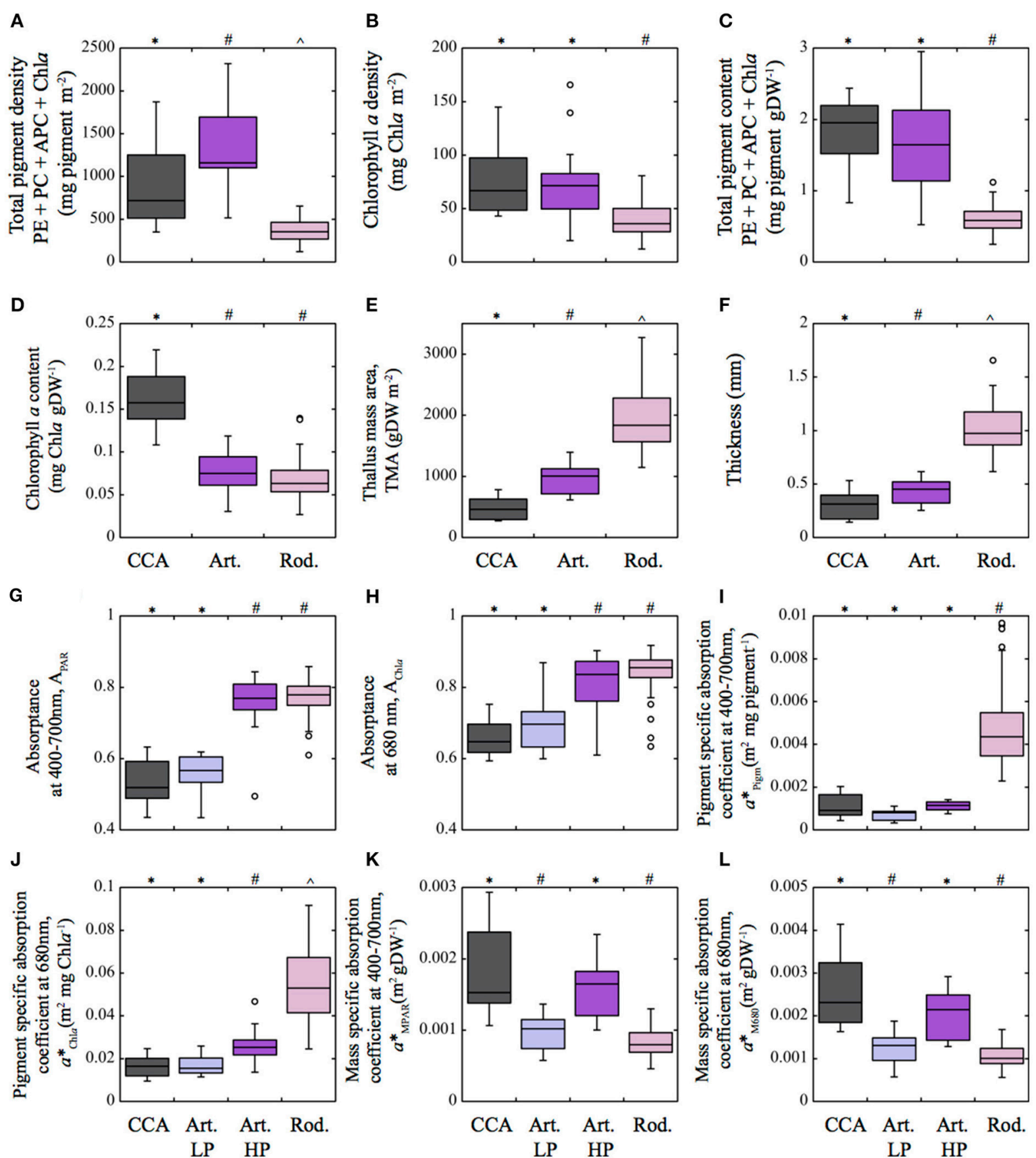

FIGURE 2 | Box plot showing the distribution of the different structural and optical thallus descriptors of the three coralline algae characterized in this study. (A) Total

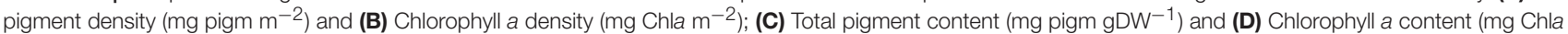
$\left.\mathrm{gDW}^{-1}\right)$; (E) Thallus mass area (TMA, gDW m $\left.{ }^{-2}\right)$; (F) thallus thickness (mm); (G) Absorptance for the PAR average (ApAR) and (H) for the Chla red peak at $680 \mathrm{~nm}$ $\left(A_{C h l a}\right)$; (I) pigment specific absorption coefficient for the PAR average $\left(a^{\star}\right.$ Pigm; $\left.\mathrm{m}^{2} \mathrm{mg} \mathrm{pigm}^{-1}\right)$ and $(\mathbf{J})$ for the Chla red peak at $680 \mathrm{~nm}^{*} \mathrm{a}^{\star} \mathrm{Chla}$; $\left.\mathrm{m}^{2} \mathrm{mg} \mathrm{Chla}{ }^{-1}\right)$; (K) mass specific absorption coefficient $\left(a^{\star}\right.$ MPAR; $\left.\mathrm{m}^{2} \mathrm{gDW}^{-1}\right)$ for the PAR average and (L) for the Chla red peak at $\left.680 \mathrm{~nm}^{\left(a^{\star} \mathrm{M} 680 ; \mathrm{m}^{2} \mathrm{gDW}\right.} \mathrm{gW}^{-1}\right)$. Total pigment refers to the sum of phycoerythrin (PE), phycocyanin (PC), allophycocyanin (APC) as well as chlorophyll a (Chla). Boxes encompass the 25 and $75 \%$ quartiles of all the data for each growth-form, the central horizontal line represents the median, bars extend to the 95\% confidence limits, and open circles represent observations extending beyond the 95\% confidence limits. Different symbols above the occurence of boxes indicate significant differences between species (one way ANOVA $P<0.05$, Tukey post-hoc $P<0.05)$. Color of the boxes: pink for the rhodolith Neogoniolithon sp; purple for the articulated alga; and gray for the crustose coralline Lithothamnion sp. (CCA). In (G-L) the purple and blue color corresponds, respectively, to the highly pigmented (HP) and lesser pigmented (LP) sides of the thalli of the articulated alga. Sample size for the descriptors: rhodoliths $n=54-63$, articulated $n=15-19$, CCA $n=12$. 


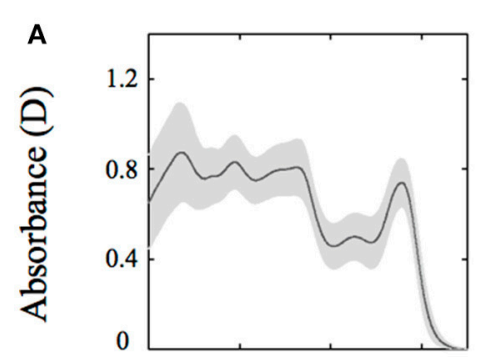

B
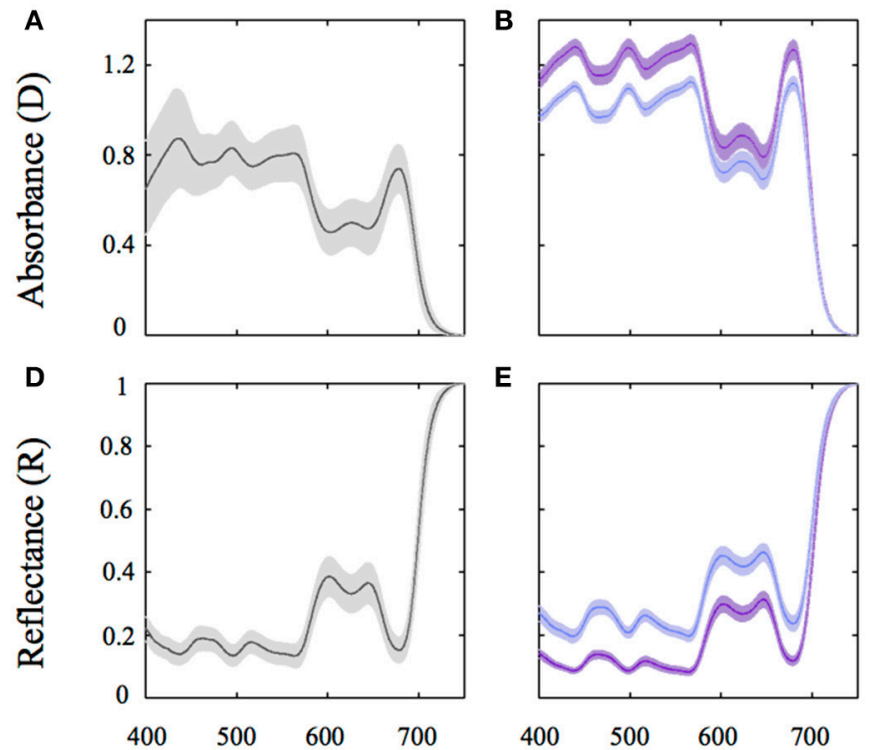

E

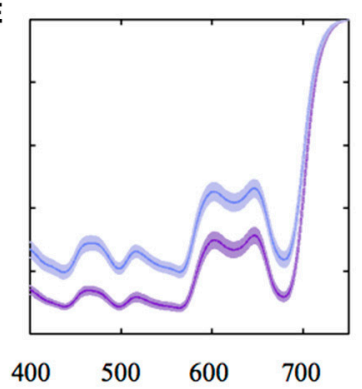

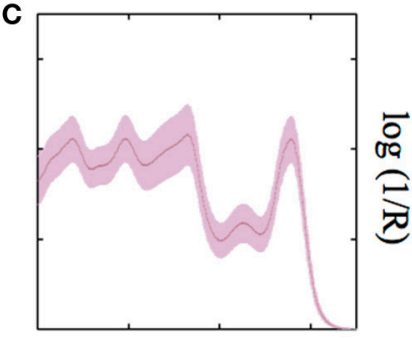

$\mathbf{F}$

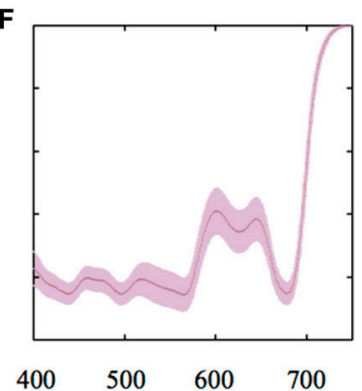

Wavelength (nm)

FIGURE 3 | Absorption and reflectance spectra of the three coralline algae characterized in this study. Average absorbance (D) for thallus spectra of the CCA Lithothamnion sp (A) and the articulated alga Amphiroa tribulus (B); Average absorption spectra of thalli of the rhodolith forming species Neogoniolithon sp. using reflectance $(R)$ determinations and the transformation $\log (1 / R)(\mathbf{C})$. (D-F) Show the respective average reflectance $(R)$ spectra of the coralline species studied. The solid line represents an average spectrum of $\geq 8$ independent spectra whereas the shaded area represents the SD of the mean. Color of the lines: pink for the rhodolith Neogoniolithon sp.; Purple and blue for highly pigmented (HP) and lesser pigmented (LP) sides of the articulated alga Amphiroa tribulus; And gray for the crustose coralline (CCA) Lithothamnion sp.

\section{Model I}

$$
\begin{aligned}
\log a^{*} \mathrm{Chl} a= & -3.13 \pm 0.22+\mathbf{0 . 2 5} \pm 0.08^{*} \log \mathrm{TMA} \\
& \mathbf{- 0 . 7 8} \pm 0.10^{*} \log \mathrm{Chl} a \mathrm{~W}\left(\mathrm{mg} \mathrm{gDW}^{-1}\right) \\
\left(R^{2}=\right. & 0.54, \mathrm{SE}=0.177, n=106, P<0.05)
\end{aligned}
$$

\section{Model II}

$$
\begin{aligned}
\log \mathrm{a}^{*}{ }_{\mathrm{M} 680}= & -0.95 \pm 0.10-\mathbf{0 . 5 3} \pm 0.04^{*} \log \mathrm{TMA} \\
& +\mathbf{0 . 2 4} \pm 0.05^{*} \log \mathrm{Chl} a \mathrm{~W}\left(\mathrm{mg} \mathrm{gDW}^{-1}\right) \\
\left(R^{2}=\right. & 0.78, \mathrm{SE}=0.08, n=88, P<0.001)
\end{aligned}
$$

The first model (Model I) indicates that increases in TMA can offset (positive effect) the strong reduction in pigment absorption efficiency, $a^{*} \mathrm{Chl} a$, that results from increases in thallus pigmentation. In contrast, the second model (Model II) supports the opposite trend on mass specific absorption $\left(a^{*} \mathrm{M} 680\right)$, as the decline in $a^{*}{ }_{\text {M680 }}$ caused by increases in TMA, can be compensated by increases in thallus pigmentation. Therefore, this quantitative description supports the existence of a morphofunctional trade-off in the regulation of the optical properties of coralline algae.

\section{Association of Variation between Optical Traits and Thallus Photosynthesis}

As optical traits are not direct descriptors of thallus photosynthesis, we examined the association of variation between optical and physiological descriptors. Significant linear and positive associations between coralline $a^{*}$ Pigm and $a^{*}{ }_{M}$ and thallus photosynthetic rates normalized to projected area $\left(R^{2}=\right.$ $0.90, P<0.05 ; n=5$; Figure S2 in SI), and to dry mass $\left(R^{2}=\right.$ $0.92, P<0.05 ; n=5$ ), were observed for the same organisms measured by Vásquez-Elizondo and Enríquez (2016). To support the generalization of these associations, however, more species and coralline morphologies need to be added to this comparison.

Estimates of coralline photosynthetic production require information about the variation in canopy size, in addition to knowledge of differences in thallus photosynthetic rates, as the size of algal canopy significantly contributes to total photosynthetic production of the whole individual. Algal canopy size was described in this study by means of the Leaf Area Index (LAI). Average LAI values for the rhodolith, articulated alga, and CCA were, respectively, $1.27 \pm 0.1,1.95 \pm 0.17$ and $1.15 \pm 0.01$ (Table S1 in SI). According to these values, the three dimensional-(3D) ramification pattern of the rhodolith and the articulated alga allow both morphologies to achieve LAI values above 1 , whereas the $2 \mathrm{D}$-structure of the CCA constrains this growth-form to values close to 1 (Figure 6A). LAI variability for each species population within the reef lagoon of Puerto Morelos, however, showed significant differences (Figure 6B). The articulated alga was the species that constructed the largest canopies (LAI $\sim 2.5$; Figure 6B; Figure S1 in SI), while variability in LAI was minimal for the CCA associated with small protuberances on its surface, which explain the 

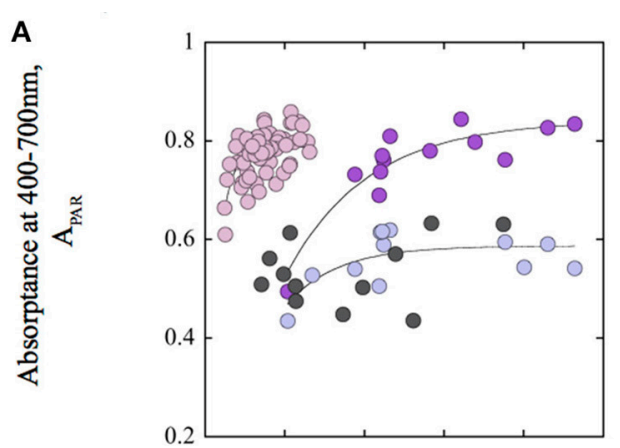

C

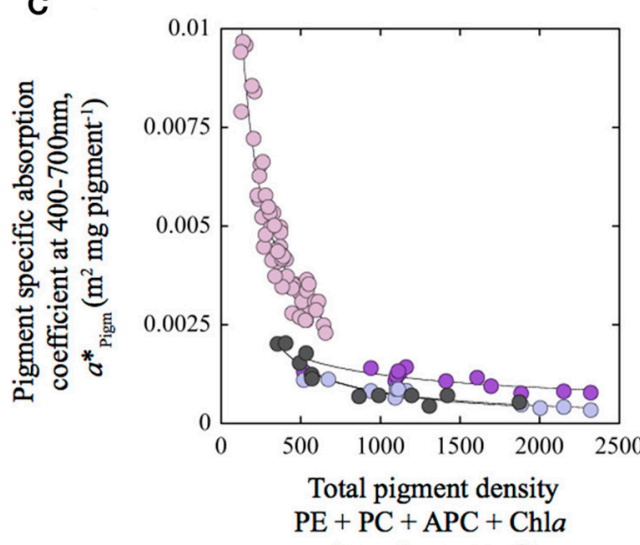

E

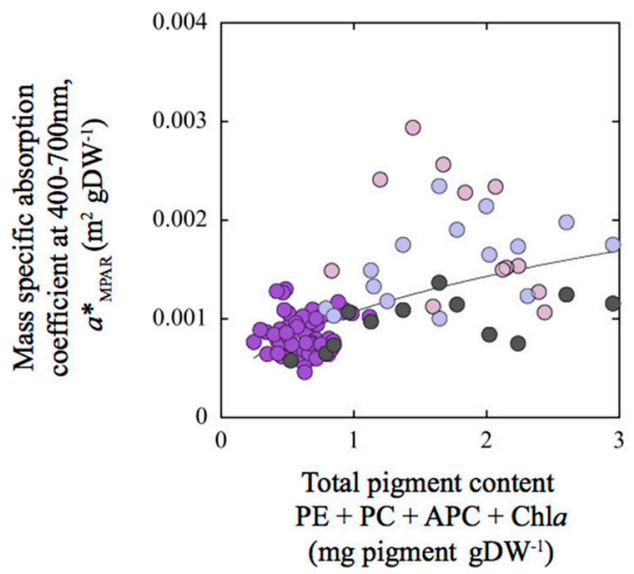

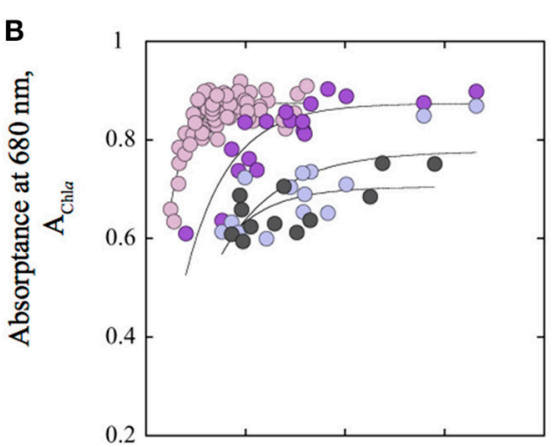

D

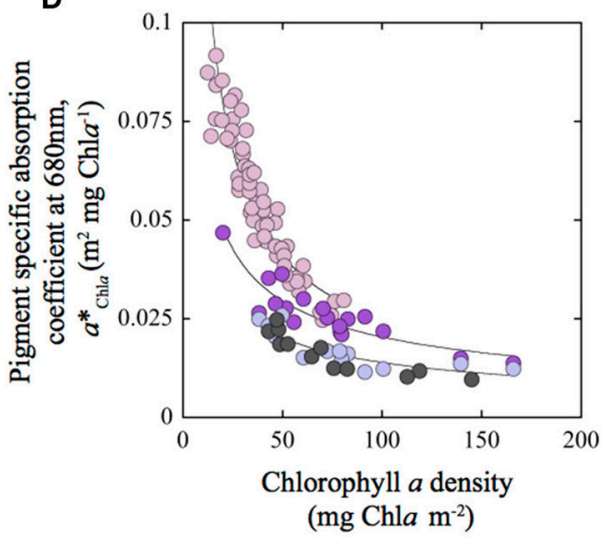

$\mathbf{F}$

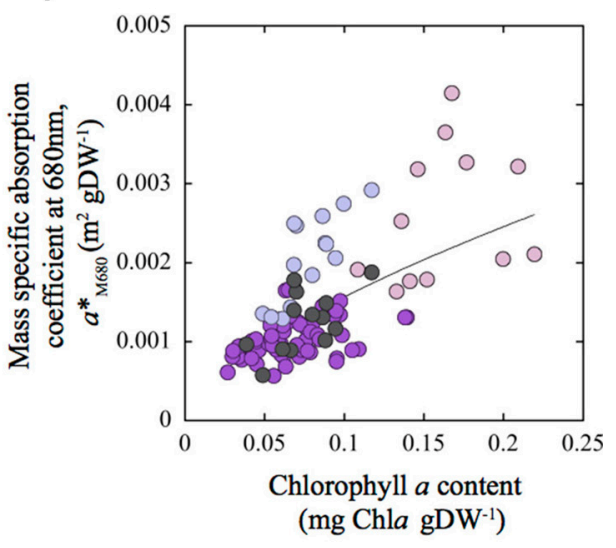

FIGURE 4 | Variation of the optical descriptors as a function of changes in thallus pigmentation for the three coralline algae characterized in this study. Variation of Absorptance for the PAR average (APAR) (A); for the Chla red peak at $680 \mathrm{~nm}\left(\mathrm{~A}_{\mathrm{Chla}}\right)$ (B); for pigment specific absorption coefficients for the PAR average $\left(a^{*}\right.$ Pigm; $\mathrm{m}^{2}$

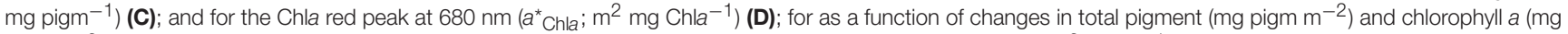
Chla $\mathrm{m}^{-2}$ ) density respectively. Variation of mass specific absorption coefficients for the PAR average (a $a^{*} \mathrm{MPAR} ; \mathrm{m}^{2} \mathrm{~g} \mathrm{DW}^{-1}$ ) (E); and for the Chla red peak at $680 \mathrm{~nm}$ $\left(a^{*} \mathrm{M} 680 ; \mathrm{m}^{2} \mathrm{~g} \mathrm{DW}^{-1}\right) \mathbf{( F )}$ as a function of changes in, respectively, total pigment content (PigmW; mg pigm $\mathrm{gDW}^{-1}$ ) and chlorophyll a content (ChlaW; mg Chla $\mathrm{gDW}^{-1}$ ). Total pigment refers to the sum of phycoerythrin (PE), phycocyanin (PC), allophycocyanin (APC) as well as, chlorophyll a (Chla). Colors of the symbols: pink for the rhodolith Neogoniolithon sp.; purple and blue, for the highly pigmented (HP) and lesser pigmented (LP) sides of the thalli of the articulated alga Amphiroa tribulus; and gray for the crustose coralline (CCA) Lithothamnion sp. Solid lines correspond to a power function fit $\left[y=a^{*} x^{b}\right.$ ] representing species-specific trends (A-D) and the common trend found for the three species (E,F).

slightly higher values above 1 estimated for this simple $2 \mathrm{D}$ morphology. Estimations of photosynthetic production per individual per hour exhibited large differences among the three coralline growth-forms (Figure 6C). The articulated alga Amphiroa tribulus and Neogoniolithon sp. showed the highest production, while the CCA the lowest. 

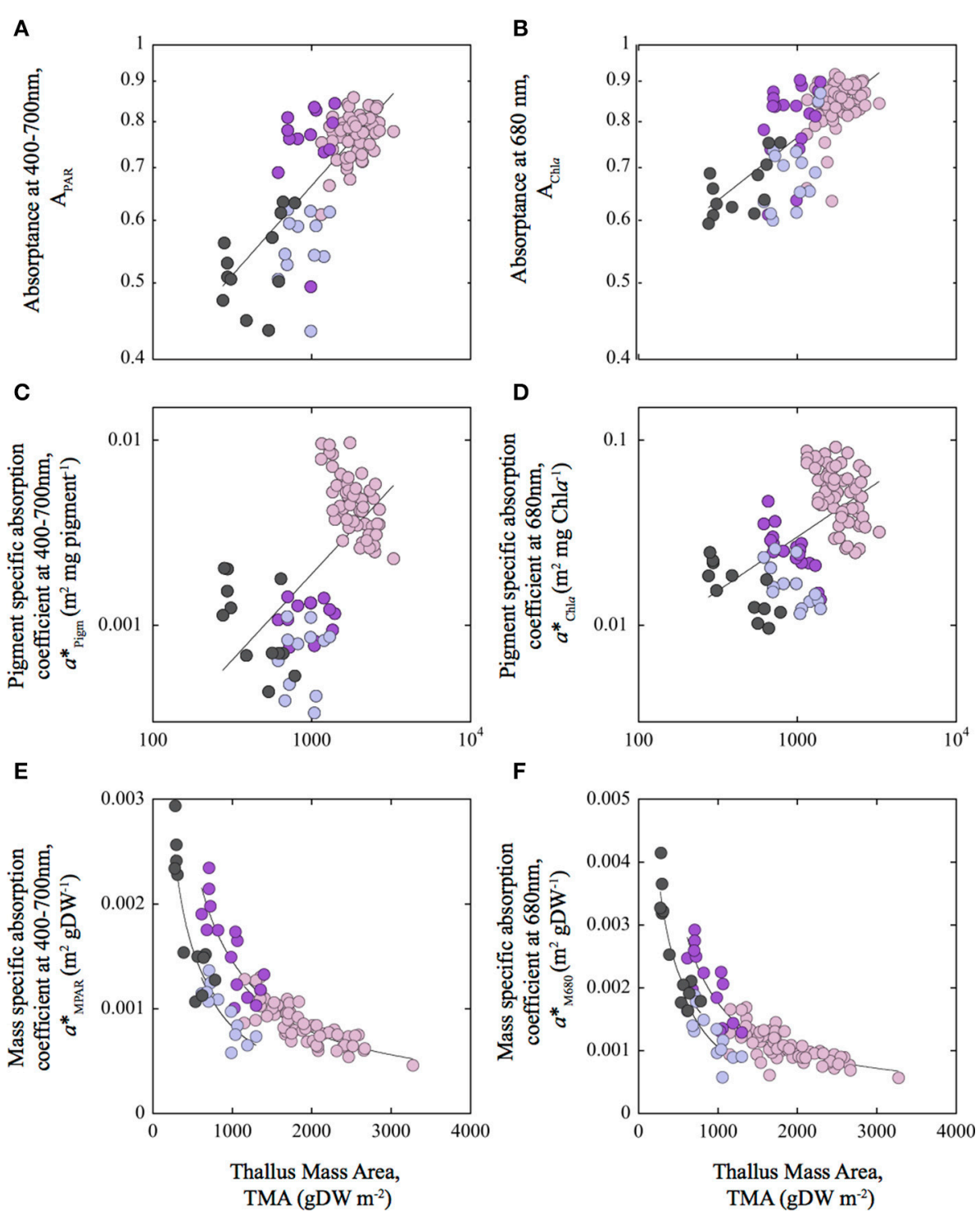

FIGURE 5 | Associations of variation between optical descriptors and Thallus Mass Area: Variation of absorptance for the PAR average (APAR) (A) and for the Chla red peak at $680 \mathrm{~nm}\left(\mathrm{~A}_{\mathrm{Chla}}\right)$ (B); for pigment specific absorption coefficients for the PAR average ( $\mathrm{a}^{*} \mathrm{Pigm} ; \mathrm{m}^{2} \mathrm{mg} \mathrm{pigm}^{-1}$ ) (C) and for the Chla red peak at $680 \mathrm{~nm}\left(\mathrm{a}^{*} \mathrm{Chla}\right)$ (D); and for mass specific absorption coefficients for the PAR average $\left(a^{*} \mathrm{MPAR} ; \mathrm{m}^{2} \mathrm{~g} \mathrm{DW}^{-1}\right)$ (E) and for the Chla red peak at $680 \mathrm{~nm}\left(a^{*} \mathrm{M} 680\right)$ (F), as a function of changes in thallus mass area (TMA). Colors of the symbols: pink, for the rhodolith Neogoniolithon sp.; purple and blue for the highly pigmented (HP) and lesser pigmented (LP) sides of the thalli of the articulated alga Amphiroa tribulus; and gray for the crustose coralline (CCA) Lithothamnion sp. Solid lines correspond to a power function fit $\left[y=a^{\star} x^{b}\right]$ representing the general trend observed among species (A-D), and the species-specific trends (E,F). Note the axis in log scale in (A-D).

\section{DISCUSSION}

This first optical characterization of coralline algae revealed that, on average, the three species examined reflected between 10 and $30 \%$ of the incident light, which represent values up to three times higher than those previously described for non-calcifying tissues (Lüning and Dring, 1985; Bauerle et al., 2004; Enríquez, 2005; Durako, 2007), but below reflectance of pubescent (Ehleringer et al., 1976) or stressed (Carter and Knapp, 2001) terrestrial leaves. Such high back-scattering supports the technical challenge that this important group of marine primary producers has represented for the development of optical studies. Our characterization indicates that the optical properties of coralline thalli follow similar trends to those previously described for non-calcified photosynthetic tissues of aquatic macrophytes (e.g., Enríquez et al., 1992, 1994; Enríquez and Sand-Jensen, 2003; Enríquez, 2005). Increases in thallus pigmentation result in non-linear declines in pigment absorption efficiency, as predicted by the "pigment packaging effect" (Morel and Bricaud, 1981; Kirk, 1994; Enríquez and Sand-Jensen, 2003). However, we also documented significant differences among coralline species for this common trend, with the thickest and less pigmented 
TABLE 1 | Parameters describing non-linear association between absorptance, estimated for the PAR average (APAR) and for the chlorophyll a -Chla- red peak at 680

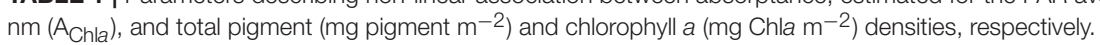

\begin{tabular}{lllllc}
\hline & Growth-form-species & $\boldsymbol{R}^{\mathbf{2}}$ & $\mathbf{A}_{\max }$ & $\boldsymbol{b}$ & $\boldsymbol{A}_{\max }: \boldsymbol{b}$ \\
\hline APAR & Rhodoliths-Neogoniolithon sp. & 0.33 & $0.78 \pm 0.006$ & $0.014 \pm 0.001$ & 55.7 \\
& Articulated-Amphiroa tribulus (HP) & 0.85 & $0.84 \pm 0.02$ & $0.019 \pm 0.0002$ & $0.003 \pm 0.0006$ \\
(LP) & 0.5 & $0.58 \pm 0.01$ & & \\
CCA - Lithothamnion sp. & $<0.05 \mathrm{~ns}$ & & $0.11 \pm 0.005$ \\
AChla & Rhodoliths-Neogoniolithon sp. & 0.72 & $0.87 \pm 0.004$ & $0.04 \pm 0.004$ & 7.9 \\
& Articulated-Amphiroa tribulus (HP) & 0.74 & $0.87 \pm 0.017$ & $0.03 \pm 0.006$ & 21.7 \\
(LP) & 0.43 & $0.77 \pm 0.03$ & $0.04 \pm 0.008$ & 17.5
\end{tabular}

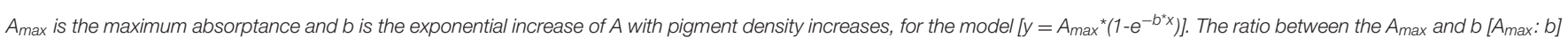

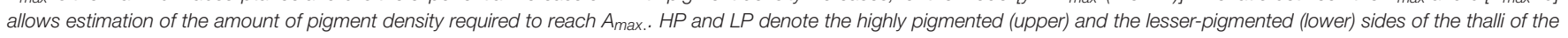
articulated algae Amphiroa tribulus.

TABLE 2 | Equations derived from Least Squares (LS) regression analysis of log-log transformed data, describing the variation of the optical descriptors as a function of changes in the structural traits of the three coralline algae characterized in this study: the rhodolith Neogoniolithon sp., the articulated alga Amphiroa tribulus, and the crustose coralline algae (CCA) Lithothamnion sp.

\begin{tabular}{|c|c|}
\hline Equation (log-log) & Statistics \\
\hline $\begin{array}{l}\log a^{\star} \text { Pigm }=0.49( \pm 0.12)- \\
1.22( \pm 0.04)^{\star} \log \text { Pigm }\end{array}$ & $\begin{array}{l}\left(R^{2}=0.87, n=94, \text { S.E. }=0.13\right. \\
P \leq 0.001)\end{array}$ \\
\hline $\begin{array}{l}\log a^{\star} \text { Chla }=0.17( \pm 0.08)- \\
1.11( \pm 0.05)^{\star} \log \text { Chla }\end{array}$ & $\begin{array}{l}\left(R^{2}=0.77, n=106, \text { S.E. }=0.12\right. \\
P \leq 0.001)\end{array}$ \\
\hline $\begin{array}{l}\log a^{\star}{ }_{\text {MPAR }}=-2.97( \pm 0.01)+ \\
0.64( \pm 0.05)^{\star} \log \text { PigmW }\end{array}$ & $\begin{array}{l}\left(R^{2}=0.41, n=96, \text { S.E. }=0.13\right. \\
P \leq 0.001)\end{array}$ \\
\hline $\begin{array}{l}\log a^{\star} \mathrm{M} 680=-2.15( \pm 0.08)+ \\
0.96( \pm 0.06)^{\star} \log \text { ChlaW }\end{array}$ & $\begin{array}{l}\left(R^{2}=0.45, n=102, \text { S.E. }=0.13\right. \\
P \leq 0.001)\end{array}$ \\
\hline $\begin{array}{l}\log \text { APAR }=-0.85( \pm 0.06)+ \\
0.30( \pm 0.02)^{\star} \log \text { TMA }\end{array}$ & $\begin{array}{l}\left(R^{2}=0.55, n=94, \text { S.E. }=0.05\right. \\
P \leq 0.001)\end{array}$ \\
\hline $\begin{array}{l}\log A_{C h l a}=-0.59( \pm 0.04)+ \\
0.22( \pm 0.01)^{\star} \log \text { TMA }\end{array}$ & $\begin{array}{l}\left(R^{2}=0.51, n=107, \text { S.E. }=0.03\right. \\
P \leq 0.001)\end{array}$ \\
\hline $\begin{array}{l}\log a^{\star} \text { Pigm }=-5.51( \pm 0.37)+ \\
1.37( \pm 0.12)^{\star} \log \text { TMA }\end{array}$ & $\begin{array}{l}\left(R^{2}=0.37, n=94, \text { S.E. }=0.30\right. \\
P \leq 0.001)\end{array}$ \\
\hline $\begin{array}{l}\log a^{\star} \text { Chla }=-3.26( \pm 0.27)+ \\
1.03( \pm 0.09)^{\star} \log \text { TMA }\end{array}$ & $\begin{array}{l}\left(R^{2}=0.29, n=107, \text { S.E. }=0.21\right. \\
P \leq 0.001)\end{array}$ \\
\hline $\begin{array}{l}\log a^{*} \text { MPAR }=-1.19( \pm 0.11)- \\
0.68( \pm 0.03)^{\star} \log \text { TMA }\end{array}$ & $\begin{array}{l}\left(R^{2}=0.71, n=96, \text { S.E. }=0.09\right. \\
P \leq 0.001)\end{array}$ \\
\hline $\begin{array}{l}\log a^{\star} M 680=-0.89( \pm 0.11)- \\
0.74( \pm 0.03)^{\star} \log \text { TMA }\end{array}$ & $\begin{array}{l}\left(R^{2}=0.74, n=102, \text { S.E. }=0.09\right. \\
P \leq 0.001)\end{array}$ \\
\hline
\end{tabular}

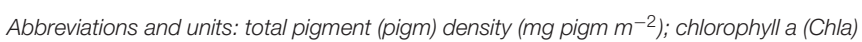
density ( $m g$ Chla $\mathrm{m}^{-2}$ ); Total pigment (PigmW) content ( $\mathrm{mg} \mathrm{pigm} \mathrm{gDW}^{-1}$ ) and chlorophyll a (ChlaW) content (mg Chla gDW-1); absorptance for the PAR average (APAR) and for the Chla red peak at $680 \mathrm{~nm}$ ( $\left.A_{C h l a}\right)$; pigment specific absorption coefficient for the PAR average ( $a^{*}$ Pigm; $m^{2} \mathrm{mg} \mathrm{pigm}^{-1}$ ) and for the Chla red peak at $680 \mathrm{~nm}\left(\mathrm{a}^{*} \mathrm{Chla} ; \mathrm{m}^{2} \mathrm{mg}\right.$ Chla $\left.{ }^{-1}\right)$; mass specific absorption coefficient for the PAR average ( $a^{*}{ }_{M P A R} ; m^{2} g W^{-1}$ ) and for the Chla red peak at $680 \mathrm{~nm}\left(\mathrm{a}^{\star} \mathrm{M680} ; \mathrm{m}^{2} \mathrm{~g} D W^{-1}\right)$; Thallus Mass Area (TMA; $g$ $D W m^{-2}$ ).

thalli of the rhodolith Neogoniolithon sp. showing significantly higher pigment absorption efficiency than the thalli of both the articulated and CCA species. These differences were explained through the positive effects of thallus pigmentation and mass area (TMA) on the capacity (A) and pigment efficiency $\left(a^{*}\right.$ pigm $)$ of light absorption, which overcome the negative correlation between TMA or thallus thickness and thallus pigmentation (Table S2 in SI), revealing similar trends documented previously for marine macrophytes (Enríquez et al., 1994) and terrestrial leaves (Vile et al., 2005). The optical theory developed for unicells does not yield with this conclusion (Duysens, 1956; Kirk, 1975, 1976, 1994; Morel and Bricaud, 1981), as this theory predicts that $a^{*}$ pigm declines with increases in both cell size and cellular pigment content. Furthermore, the first study that applied this optical descriptor, $a^{*}$ pigm, to multicellular tissues, the leaves of an amphibious plant Mentha aquatica, yielded results similar to unicells, as both parameters, leaf pigment content and leaf mass area, LMA, were negatively associated with $a^{*}$ pigm (Enríquez and Sand-Jensen, 2003). The trend documented in our comparison for three coralline species agrees with the findings of Enríquez et al. (1994), who compared $90 \mathrm{spp}$. of macroalgae and 12 of seagrasses. In that study, the authors concluded that increases in tissue thickness are more effective for enhancing absorbance $(D)$ than increases in tissue pigmentation (Enríquez et al., 1994), attributing the capacity for thick tissues to reduce "pigment packaging," to enhanced light scattering within thicker photosynthetic structures. For coralline algae, increases in thallus size result from increases in carbonate skeleton thickness. This implies that coralline skeletons may play and important role in the regulation of the optical properties of coralline thalli, as they do in symbiotic corals (Enríquez et al., 2005). This conclusion, however, is only valid when comparing different coralline morphologies, as within each species we observed the same trend documented for unicells and the leaves of Mentha aquatica (Duysens, 1956; Kirk, 1975, 1976, 1994; Morel and Bricaud, 1981; Enríquez and Sand-Jensen, 2003). According to all these findings, increases in skeleton thickness or TMA of coralline thalli may yield a morphotype with reduced pigment packaging, but it does not completely offset this phenomenon, as within any given morphology, increases in pigmentation still induce non-linear declines in pigment absorption efficiency.

Incorporating data from previous studies into the coralline interspecific $a^{*}$ Chla analysis, we observed that the rhodolith Neogoniolithon sp. had an average value similar to the Rhodophyta $a^{*}$ Chla mean recalculated from Enríquez et al. (1994) 
TABLE 3 | Slopes and intercepts of the linear associations (log-log transformed data) between the structural and optical descriptors of the three coralline species characterized in this study: the rhodolith Neogoniolithon sp., the articulated alga Amphiroa tribulus (both sides) and the crustose coralline (CCA) Lithothamnion sp.

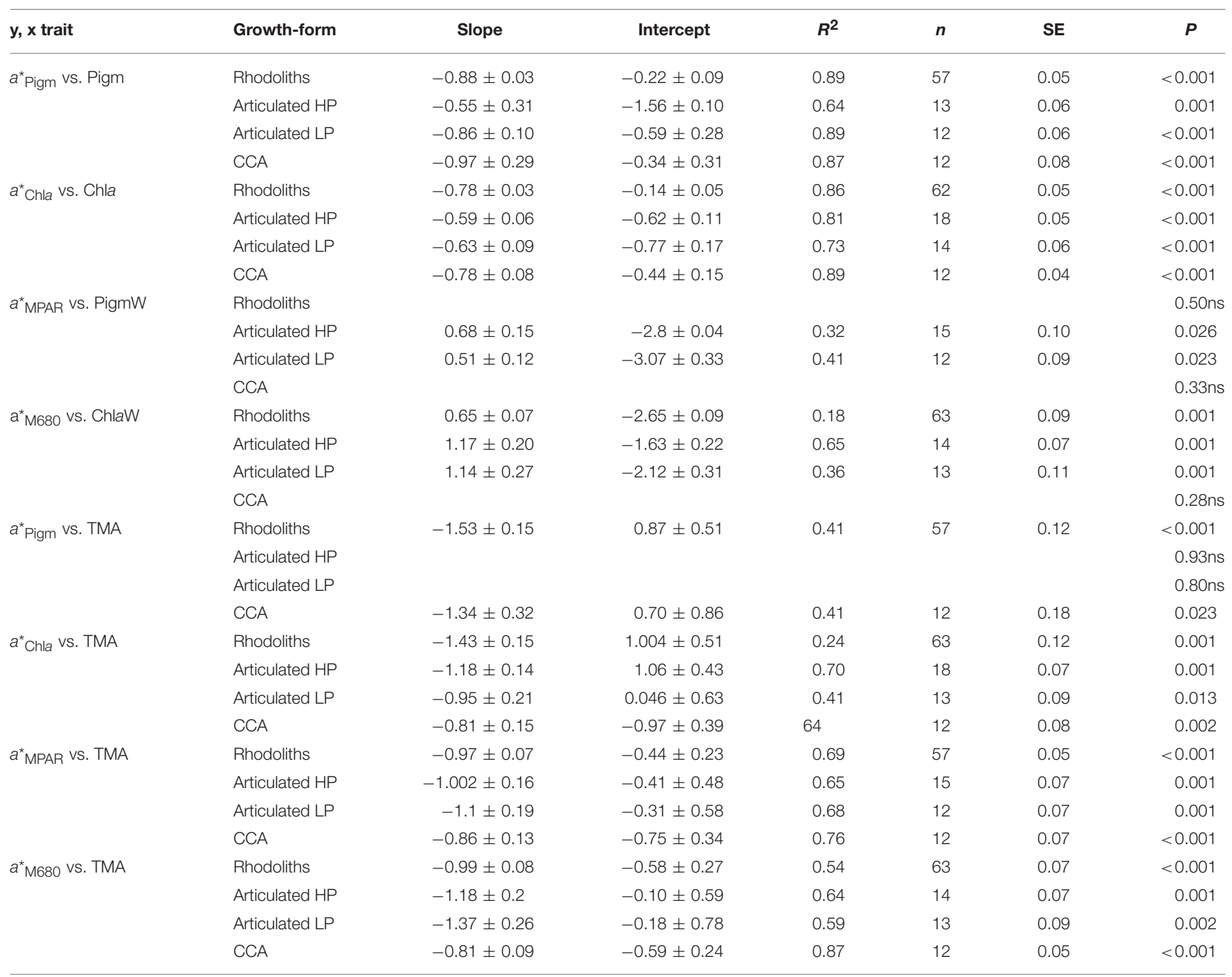

Abbreviations and units as described in Table 2.

data (Figure 7). Both average $a^{*}$ Chla values for the rhodolith (this study) and Rhodophyta (data from Enríquez et al., 1994) were significantly above the averages estimated for Amphiroa tribulus and the CCA (Figure 7). Interestingly, the scleractinian coral P. branneri was, as predicted by Enríquez et al. (2005), the photosynthetic structure with the highest $a^{*} \mathrm{Chl} a$, whereas the leaves of the two aquatic higher plants showed similar $a^{*} \mathrm{Chla}$ averages to, respectively, $A$. tribulus (T. testudinum) and the CCA (M. aquatica). To better understand these interspecific differences, we analyzed the associations of variation between $a^{*}$ Chla and chlorophyll $a$ density (Figure 7B). This inter-specific comparison revealed that the diverse group of red algae (34 spp.) characterized by Enríquez et al. (1994) displayed the largest variability within this association. Most of the species examined in that study were non-calcifying thalli, although $5 \mathrm{spp}$. were also corallines belonging to the genus Peysonnelia and Jania. It is remarkable that the three species characterized here were among the Rhodophyta with the highest $a^{*}$ Chla (Figure 7B), as supported by an ANCOVA test (intercept $t$-test $p<0.01$; Rhodophyta intercept $=-0.69 \pm 0.10$; corallines intercept $=$ $0.17 \pm 0.08$ in Table 2). No differences were found, however, for the slopes of these associations (slope $t$-test $p>0.05$ ). Values for the coral Porites branneri from Enríquez et al. (2005) showed a trend similar to that of rhodoliths (ANCOVA, $t$-test $P>0.05)$. The low chlorophyll $a$ density of the symbiotic coral explains its high $a^{*}$ Chla average (Figure 7). Rhodoliths and CCA showed significant differences for this trend (ANCOVA, intercept $t$-test, $p<0.01$, Table 3 ), supporting the notion that coralline algae with thicker thalli and higher TMA can reduce "pigment packaging" more efficiently, developing structures with higher $a^{*}$ Pigm for similar thallus pigmentation. Yet, this comparative analysis supports the conclusion that the presence of highly reflective structures (i.e., coralline carbonate skeletons) plays a key role in thallus optics of multicellular photosynthetic tissues, 

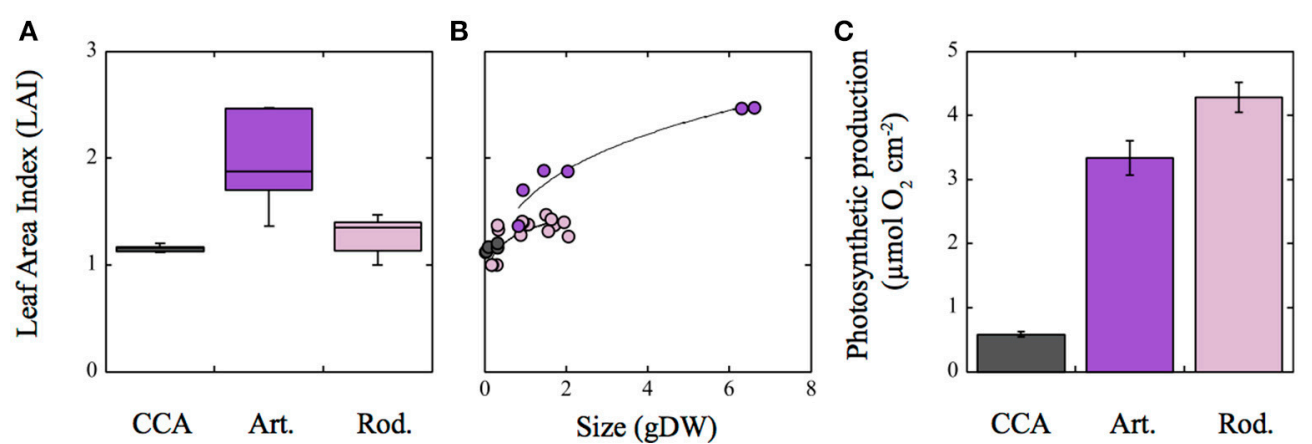

FIGURE 6 | Variation of the Leaf Area Index (LAl) in the three growth-forms of coralline algae characterized in this study. (A) Box plot describing LAl variability for each coralline growth-form; (B) variation of LAl as a function of coralline algal size in $\mathrm{g}$ DW; (C) estimated photosynthetic production for each coralline growth-form for $1 \mathrm{~h}$ assuming a constant $P_{\max }\left(\mu \mathrm{mol} \mathrm{O}_{2} \mathrm{~cm}^{-2}\right.$ ). Photosynthetic data were derived from Vásquez-Elizondo and Enríquez (2016). For (A): Boxes encompass the 25 and $75 \%$ quartiles of all data, the central horizontal line represents the median, bars extend to the $95 \%$ confidence limits, and open circles represent observations extending beyond the $95 \%$ confidence limits. Solid lines in (B) correspond to a power function fit $\left[y=a^{*} x^{b}\right]$. Colors denote: pink for the rhodolith Neogoniolithon sp.; purple for the articulated alga Amphiroa tribulus; and gray for the crustose coralline (CCA) Lithothamnion sp. Error bars in (C) correspond to SE ( $n=6)$.
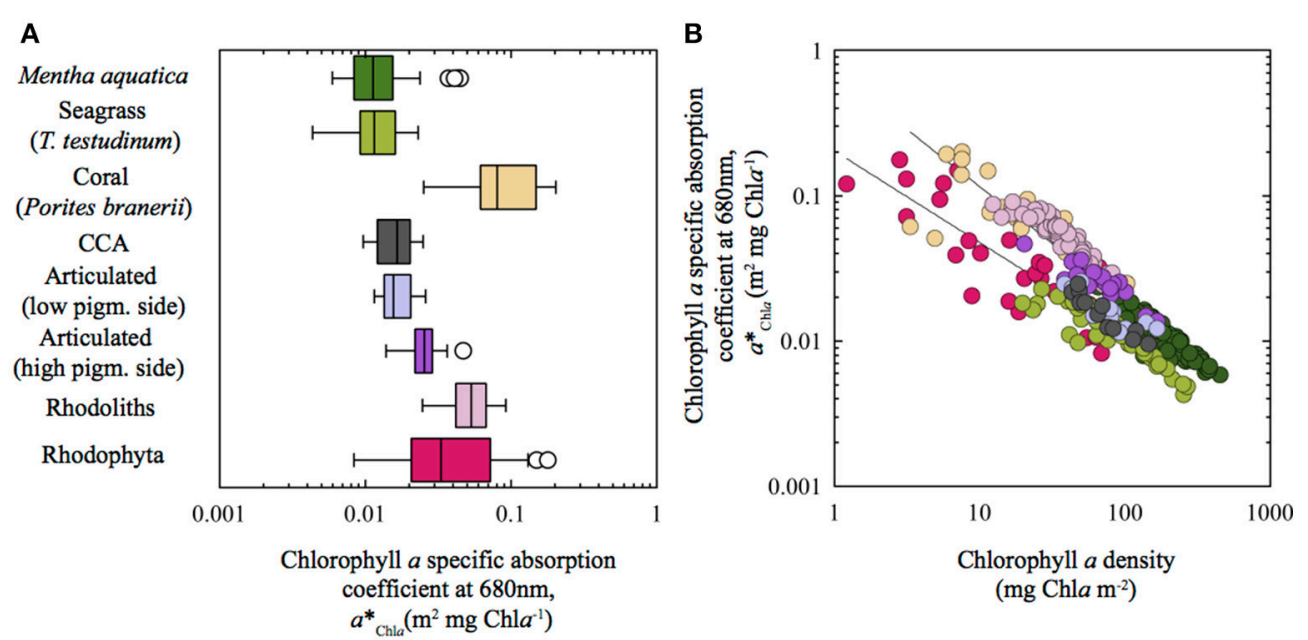

FIGURE 7 | Inter-specific variation of pigment specific absorption for the Chla red peak ( $a^{*} \mathrm{Chla}$ ) across different aquatic photosynthetic structures: (A) Box plot showing $a_{C h l a}^{*}$ variation for the different species characterized; and (B) log/log variation of $a^{*}$ Chla as a function of changes in chlorophyll a density ( $\mathrm{mg} C$ Chla $\mathrm{m}^{-2}$ ). Data from: Corallines (this study); Rhodophyta (Enríquez et al., 1994); Mentha aquatica (Enríquez and Sand-Jensen, 2003); coral Porites branerii (Enríquez et al., 2005); Thalassia testudinum (Enríquez, 2005). Trend lines in (B) correspond to power function fits $\left[y=a^{*} x^{b}\right]$ for: (1) Rhodophyta and T. testudinum (bottom trend line) and, (2) corallines (rhodoliths, articulated and CCA), Porites branerii and Mentha aquatica. LS regression analysis of the log-log transformed data: For fit (1), log $a^{*}$ Pigm $=-0.69( \pm 0.10)-0.63( \pm 0.08)^{\star} \log$ Chla $\left(R^{2}=0.76, n=26, S E=0.21, P<0.001\right.$; for fit $(2), \log a^{*}$ Pigm $=-0.15( \pm 0.07)-0.91( \pm 0.04)^{\star} \log C h l a\left(R^{2}=\right.$ $0.68, n=123, S E=0.15, P<0.001)$.

through enhancing the efficiency with which photosynthetic pigments collect solar energy. Accordingly, we may explain why the leaves of the seagrass Thalassia testudinum showed a similar positive effect of LMA on $a^{*} \mathrm{Chl} a$ (Enríquez, 2005) in contrast to the opposite trend reported for the thinner leaves of Mentha aquatica (Enríquez and Sand-Jensen, 2003), as the seagrass leaves produce oxalate crystals within the pigmented epidermal cells (Dobbs et al., 2004), and also present the ability to precipitate aragonites crystals within their cell walls (Enríquez and Schubert, 2014).

With respect to the variation of light absorption efficiency per mass $\left(a^{*}{ }_{M}\right)$, we observed in the present comparison a strong and negative association between this optical descriptor and coralline TMA, in accordance with previous analyses (Enríquez et al., 1994; Enríquez and Sand-Jensen, 2003). Significant differences for the effect of TMA on $a^{*}{ }_{\mathrm{M}}$ variation were also found among the three coralline species. Both, CCA and the articulated alga showed the highest $a^{*}$ M values and the largest reductions in $a^{*}{ }_{\mathrm{M}}$ as TMA increases. Rhodoliths, in contrast, had the lowest $a^{*} \mathrm{M}$ and a reduced sensitivity to change $a^{*}{ }_{M}$ with TMA variation. Therefore, our comparison also supports the utility of $a^{*} \mathrm{M}$ to quantify functional differences among species, although we agree with Falkowski et al. (1985) and Ramus (1990), that this parameter is a mathematical construction as only photosynthetic 
pigments have a real absorption cross-section. Mass or carbon specific absorption has been proposed as a functional descriptor for the efficiency of the photosynthetic light collector to return the energy collected to structural mass or carbon (Ramus, 1990; Enríquez et al., 1994; Enríquez and Sand-Jensen, 2003). Our study supports this interpretation but also the existence of a potential trade-off between both optical traits $\left(a^{*}\right.$ and $\left.a^{*}{ }_{\mathrm{M}}\right)$. According to this trade-off, species with thick structures, low pigmentation and high TMA can reduce pigment content and thus the amount of nitrogen required to build the light collector (high $a^{*}$ Pigm) at the expense of increasing its structural costs (carbon) and diminishing the return of the solar energy collected into new structural carbon $\left(\right.$ lower $\mathrm{a}^{*}{ }_{\mathrm{M}}$ ). In contrast, thin and cheap photosynthetic structures can minimize the structural costs of their thalli and maximize carbon return (higher $a^{*}{ }_{M}$ ), at the expense of increasing "pigment packaging" (lower $a^{*} \mathrm{Chl} a$ ) and the construction costs of the photosynthetic apparatus in terms of pigment and nitrogen investments. The first strategy, represented by the rhodolith Neogoniolithon sp., would be an optimal solution for colonizing oligotrophic and highly illuminated environments, while the second option, represented by the CCA Lithothamnion sp., would maintain positive carbon balances under extremely low light conditions within the reef framework. The ecological and/or evolutionary success of the articulated alga Amphiroa tribulus, which combines both strategies in a specialized bifacial thallus, may not depend on its complex thallus optics, but on its ability to construct large 3D-canopies. We estimated for $A$. tribulus intermediate values in thallus light absorption efficiency, metabolic rates and TMA, but photosynthetic production per individual was as high as that of the rhodolith, thanks to its ability to form one the largest light collectors at the organism/canopy level. For the quantification of the size of the light collector of the whole organism, we used a parameter, LAI, common in terrestrial plant ecology, but not so common in marine ecology, although it has been successfully applied for the characterization of seagrass habitats (Olesen et al., 2002; Enríquez and Pantoja-Reyes, 2005; Collier et al., 2007). Seagrass LAI can explain changes in the magnitude of leaf self-shading within seagrass beds (Enríquez and Pantoja-Reyes, 2005) and leaf photoprotection (Schubert et al., 2015). In addition, LAI has been successfully applied to understand the response to depth of Jania adherens in association with a sponge (Enríquez et al., 2009). Our comparison provides new support for the functional relevance of LAI to characterize benthic communities in marine habitats.

In summary, by enhancing $a^{*}$ Chla the rhodolith Neogoniolithon sp. not only produces a more efficient light collector under nutrient limitation, but a more productive thallus with high photosynthetic rates per area. In contrast, the structurally cheap and simple crustose 2D-morphology of Lithothamnion sp. allows maximizing thallus efficiency for energy collection per structural mass. Thereby, this growthform allows maintaining positive carbon balances under the extremely limited light conditions that occur within the coral reef framework, insuring species survival. The third growth-form represented by the articulated alga Amphiroa tribulus, is able to compensate for its intermediate optical and photosynthetic thallus capabilities, by constructing large light collectors (canopies). In our simulation, this species achieved values of photosynthetic production per organism similar to the rhodoliths despite its lower thallus photosynthetic rates. Yet, the capacity to construct complex 3D-canopies explains the higher productivity of the rhodolith Neogoniolithon sp. and Amphiroa tribulus, while algal production of the simplest crustose 2D-morphology of Lithothamnion sp. depends entirely on thallus photosynthesis. Neogoniolithon sp. colonizes open areas within the reef seagrass bed, whereas A. tribulus and Lithothamnion sp. require a fixed substrate within the coral reef community. The low light specialist Lithothamnion sp. grows on cryptic habitats within the coral reef framework, while the weak canopy of $A$. tribulus finds the appropriate niche within the protection provided by colonies of the lettuce coral Agaricia agaricites (Figure S1 in SI). Our analysis, therefore, supports the utility of optical traits in marine ecology, as powerful tools to investigate differences in competitive abilities, morphofunctional constraints, abundances and niche distribution among algal species and growth-forms.

\section{AUTHOR CONTRIBUTIONS}

$\mathrm{SE}$ designed research, RV performed research, RV and SE analyzed data and wrote the paper.

\section{ACKNOWLEDGMENTS}

Two Mexican research projects granted to SE, DGAPA (IN206710) and CONACYT (Conv-CB-2009: 129880), provided financial support to this research, which was part of the $\mathrm{PhD}$ thesis of $\mathrm{RV}$ in the postgraduate program of the Universidad Nacional Autónoma de México (UNAM- Posgrado en Ciencias del Mar y Limnología-PCMyL). The Mexican Consejo Nacional de Ciencia y Tecnología (CONACyT) is acknowledged for providing 4 years Ph.D fellowship to support RV. We thank Darren Brown for useful comments on the manuscript and Roberto Iglesias-Prieto for his valuable input, optimism, technical support and "good energy" during the development of this project. The experiments performed in this work comply with the current laws of Mexico. An ethics approval was not required as per national regulations. The study was supported by the Mexican permit: "Permiso de Pesca de Fomento" No PPF/DGOPA-031/13, to SE; issued by the Secretaría de Agricultura, Ganadería, Desarrrollo rural, Pesca y Alimentación of the United States of Mexico, to support the development of the project: "Evaluación del efecto de la limitación de carbono sobre diferentes productores primarios de la laguna arrecifal de Puerto Morelos: Importancia de la calcificación."

\section{SUPPLEMENTARY MATERIAL}

The Supplementary Material for this article can be found online at: http://journal.frontiersin.org/article/10.3389/fmars. 2017.00297/full\#supplementary-material 


\section{REFERENCES}

Adey, W. H. (1998). Coral reefs: algal structured and mediated ecosystems in shallow, turbulent, alkaline waters. J. Phycol. 34, 393-406. doi: $10.1046 /$ j.1529-8817.1998.340393.x

Algarra, P., and Niell, F. X. (1987). Structural adaptations to light reception in two morphotypes of Corallina elongata ELLIS and SOLAND. Mar. Ecol. 8, 253-261. doi: 10.1111/j.1439-0485.1987.tb00187.x

Bauerle, W. L., Weston, D. J., Bowden, J. D., Dudley, J. B., and Toler, J. E. (2004). Leaf absorptance of photosynthetically active radiation in relation to chlorophyll meter estimates among woody plant species. Sci. Horticult. 101, 169-178. doi: 10.1016/j.scienta.2003.09.010

Bensoussan, N., and Gattuso, J.-P. (2007). Community primary production and calcification in a NW Mediterranean ecosystem dominated by calcareous macroalgae. Mar. Ecol. Prog. Ser. 334, 37-45. doi: 10.3354/meps334037

Björkman, O. (1981). "Responses to different quantum flux densities," in Physiological Plant Ecology I: Responses to the Physical Environment, eds O. L. Lange, P. S. Nobel, C. B. Osmond, and H. Ziegler (Berlin; Heidelberg: Springer Berlin Heidelberg), 57-107.

Burdett, H. L., Keddie, V., MacArthur, N., McDowall, L., McLeish, J., Spielvogel, E., et al. (2014). Dynamic photoinhibition exhibited by red coralline algae in the red sea. BMC Plant Biol. 14:139. doi: 10.1186/1471-2229-14-139

Carter, G. A., and Knapp, A. K. (2001). Leaf optical properties in higher plants: linking spectral characteristics to stress and chlorophyll concentration. Am. J. Bot. 88, 677-684. doi: 10.2307/2657068

Cayabyab, N. M., and Enríquez, S. (2007). Leaf photoacclimatory responses of the tropical seagrass Thalassia testudinum under mesocosm conditions: a mechanistic scaling-up study. New Phytol. 176, 108-123. doi: 10.1111/j.1469-8137.2007.02147.x

Chisholm, J. R. M. (2003). Primary productivity of reef-building crustose coralline algae. Limnol. Oceanogr. 48, 1376-1387. doi: 10.4319/lo.2003.48.4.1376

Collier, C. J., Lavery, P. S., Masini, R. J., and Ralph, P. J (2007). Morphological, growth and meadow characteristics of the seagrass Posidonia sinuosa along a depth-related gradient of light availability. Mar. Ecol. Prog. Ser. 337, 103-115. doi: $10.3354 /$ meps 337103

de la Riva, E. G., Olmo, M., Poorter, H., Ubera, J. L., and Villar, R. (2016). Leaf Mass per Area (LMA) and its relationship with leaf structure and anatomy in 34 mediterranean woody species along a water availability gradient. PLOS ONE 11:e0148788. doi: 10.1371/journal.pone.0148788

Dobbs, F. C., Zimmerman, R. C., and Drake, L. A. (2004). Occurrence of intracellular crystals in leaves of Thalassia testudinum. Aquat. Bot. 80, 23-28. doi: 10.1016/j.aquabot.2004.03.003

Durako, M. J. (2007). Leaf optical properties and photosynthetic leaf absorptance in several Australian seagrasses. Aquat. Bot. 87, 83-89. doi: 10.1016/j.aquabot.2007.03.005

Duysens, L. N. (1956). The flattening of the absorption spectrum of suspensions, as compared to that of solutions. Biochim. Biophys. Acta 19, 1-12. doi: 10.1016/0006-3002(56)90380-8

Ehleringer, J., Björkman, O., and Mooney, H. A. (1976). Leaf pubescence: effects on absorptance and photosynthesis in a desert shrub. Science 192, 376-377. doi: $10.1126 /$ science.192.4237.376

Enríquez, S. (2005). Light absorption efficiency and the package effect in the leaves of the seagrass Thalassia testudinum. Mar. Ecol. Prog. Ser. 289, 141-150. doi: 10.3354/meps 289141

Enríquez, S., Agustí, S., and Duarte, C. (1992). Light absorption by seagrass Posidonia oceanica leaves. Mar. Ecol. Prog. Ser. 86, 201-201. doi: 10.3354/meps086201

Enríquez, S., Agustí, S., and Duarte, C. M. (1994). Light absorption by marine macrophytes. Oecologia 98, 121-129. doi: 10.1007/BF00341462

Enríquez, S., Ávila, E., and Carballo, J. L. (2009). Phenotypic plasticity induced in transplant experiments in a mutualistic association between the red alga Jania adhaerens (Rhodophyta, Corallinales) and the sponge haliclona caerulea (Porifera: Haplosclerida): morphological responses of the alga. J. Phycol. 45, 81-90. doi: 10.1111/j.1529-8817.2008.00640.x

Enríquez, S., Méndez, E. R., Hoegh-Guldberg, O., and Iglesias-Prieto, R. (2017). Key functional role of the optical properties of coral skeletons in coral ecology and evolution. Proc. R. Soc. B Biol. Sci. 284:20161667. doi: 10.1098/rspb.2016.1667
Enríquez, S., Méndez, E. R., and Iglesias-Prieto, R. (2005). Multiple scattering on coral skeletons enhances light absorption by symbiotic algae. Limnol. Oceanogr. 50, 1025-1032. doi: 10.4319/lo.2005.50.4.1025

Enríquez, S., and Pantoja-Reyes, N. (2005). Form-function analysis of the effect of canopy morphology on leaf self-shading in the seagrass Thalassia testudinum. Oecologia 145, 235-243. doi: 10.1007/s00442-0050111-7

Enríquez, S., and Sand-Jensen, K. (2003). Variation in light absorption properties of Mentha aquatica L. as a function of leaf form: implications for plant growth. Int. J. Plant Sci. 164, 125-136. doi: 10.1086/344759

Enríquez, S., and Schubert, N. (2014). Direct contribution of the seagrass Thalassia testudinum to lime mud production. Nat. Commun. 5:3835. doi: $10.1038 /$ ncomms 4835

Evans, J. R., and Poorter, H. (2001). Photosynthetic acclimation of plants to growth irradiance: the relative importance of specific leaf area and nitrogen partitioning in maximizing carbon gain. Plant Cell Environ. 24, 755-767. doi: 10.1046/j.1365-3040.2001.00724.x

Falkowski, P. G., Dubinsky, Z., and Wyman, K. (1985). Growth-Irradiance relationships in phytoplankton. Limnol. Oceanogr. 30, 311-321. doi: $10.4319 /$ lo.1985.30.2.0311

Foster, M. S. (2001). Rhodoliths: between rocks and soft places. J. Phycol. 37, 659-667. doi: 10.1046/j.1529-8817.2001.00195.x

Frost-Christensen, H., and Sand-Jensen, K. (1992). The quantum efficiency of photosynthesis in macroalgae and submerged angiosperms. Oecologia 91, 377-384. doi: 10.1007/BF00317627

Garnier, E., Cordonnier, P., Guillerm, J.-L., and Sonié, L. (1997). Specific leaf area and leaf nitrogen concentration in annual and perennial grass species growing in Mediterranean old-fields. Oecologia 111, 490-498. doi: $10.1007 / \mathrm{s} 004420050262$

Häder, D.-P., Lebert, M., Flores-Moya, A., Jiménez, C., Mercado, J., Salles, S., et al. (1997). Effects of solar radiation on the photosynthetic activity of the red alga Corallina elongata Ellis et Soland. J. Photochemi. Photobiol. B Biol. 37, 196-202. doi: 10.1016/S1011-1344(96)07402-7

Heyward, A. J., and Negri, A. P. (1999). Natural inducers for coral larval metamorphosis. Coral Reefs 18, 273-279. doi: 10.1007/s003380050193

Hoegh-Guldberg, O., Mumby, P. J., Hooten, A. J., Steneck, R. S., Greenfield, P., Gomez, E., et al. (2007). Coral reefs under rapid climate change and ocean acidification. Science 318, 1737-1742. doi: 10.1126/science. 1152509

Iglesias-Prieto, R., and Trench, R. K. (1997). "Photoadaptation, photoacclimation and niche diversification in invertebrate-dinoflagellate symbioses," in Proceedings of the 8th International Coral Reef Symposium (Panama), 1319-1324.

Johansen, H. W. (1981). Coralline Algae, A First Synthesis. Boca Raton, FL: CRC Press.

Kirk, J. T. O. (1975). A theoretical analysis of the contribution of algal cells to the attenuation of light within natural waters I. General treatment of suspensions of pigmented cells. New Phytol. 75, 11-20. doi: $10.1111 /$ j.1469-8137.1975.tb01366.x

Kirk, J. T. O. (1976). A theoretical analysis of the contribution of algal cells to the attenuation of light natural waters. New Phytol. 77, 341-358. doi: 10.1111/j.1469-8137.1976.tb01524.x

Kirk, J. T. O. (1994). Light and Photosynthesis in Aquatic Ecosystems, 2nd Edn. Cambridge: Cambridge Uniersity Press.

Kursar, T., van der Meer, J., and Alberte, R. (1983). Light-harvesting system of the red alga Gracilaria tikvahiae: I. Biochemical analyses of pigment mutations. Plant Physiol. 73, 353-360. doi: 10.1104/pp.73.2.353

Lichtenthaler, H. K., and Wellburn, A. R. (1983). Determination of total carotenoids and chlorophylls $\mathrm{a}$ and $\mathrm{b}$ of leaf extracts in different solvents. Biochem. Soc. Trans. 11, 591-592. doi: 10.1042/bst0110591

Littler, M. M. (1972). The crustose corallinaceae. Oceanogr. Mar. Biol. 10, 103-120.

Littler, M. M., and Doty, M. S. (1975). Ecological components structuring the seaward edges of tropical pacific reefs: the distribution, communities and productivity of porolithon. J. Ecol. 63, 117-129. doi: 10.2307/225 8846

Littler, M. M., Littler, D. S., Blair, S. M., and Norris, J. N. (1985). Deepest known plant life discovered on an uncharted seamount. Science 227, 57-59. doi: $10.1126 /$ science.227.4682.57 
Lüning, K., and Dring, M. J. (1985). Action spectra and spectral quantum yield in marine macroalgae with thin and thick thalli. Mar. Biol. 87, 119-129. doi: 10.1007/BF00539419

Markager, S., and Sand-Jensen, K. (1992). Light requirements and depth zonation of marine macroalgae. Mar. Ecol. Prog. Ser. 88, 83-83. doi: 10.3354/meps088083

Marsh, J. A. (1970). Primary productivity on reef-building calcareous red algae. Ecology 51, 255-263. doi: 10.2307/1933661

Martin, S., Castets, M.-D., and Clavier, J. (2006). Primary production, respiration and calcification of the temperate free-living coralline alga Lithothamnion corallioides. Aquat. Bot. 85, 121-128. doi: 10.1016/j.aquabot.2006. 02.005

McCoy, S., and Kamenos, N. A. (2015). Coralline algae (Rhodophyta) in a changing world: integrating ecological, physiological, and geochemical responses to global change. J. Phycol. 51, 6-24. doi: 10.1111/jpy.12262

Mercado, J. M., Jiménez, C., Niell, F. X., and Figueroa, F. L. (1996). Comparison of methods for measuring light absorption by algae and their application to the estimation of the package effect. Sci. Mar. 60, 39-45.

Morel, A., and Bricaud, A. (1981). Theoretical results concerning lightabsorption in a discrete medium, and application to specific absorption of phytoplankton. Deep Sea Res. A. Oceanogr. Res. Pap. 28, 1375-1393. doi: 10.1016/0198-0149(81)90039-X

Olesen, B., Enríquez, S., Duarte, C. M., and Sand-Jensen, K. (2002). Depth-acclimation of photosynthesis, morphology and demography of Posidonia oceanica and Cymodocea nodosa in the Spanish Mediterranean Sea. Mar. Ecol. Prog. Ser. 236, 89-97. doi: 10.3354/meps23 6089

Payri, C. E., Maritorena, S., Bizeau, C., and Rodière, M. (2001). Photoacclimation in the tropical coralline alga Hydrolithon onkodes (Rhodophyta, Corallinaceae) from a French Polynesian reef. J. Phycol. 37, 223-234. doi: $10.1046 /$ j.1529-8817.2001.037002223.x

Perry, C. T., and Hepburn, L. J. (2008). Syn-depositional alteration of coral reef framework through bioerosion, encrustation and cementation: taphonomic signatures of reef accretion and reef depositional events. Earth Sci. Rev. 86, 106-144. doi: 10.1016/j.earscirev.2007.08.006

Perry, C. T., Spencer, T., and Kench, P. S. (2008). Carbonate budgets and reef production states: a geomorphic perspective on the ecological phase-shift concept. Coral Reefs 27, 853-866. doi: 10.1007/s00338-0080418-z

Poorter, H., and De Jong, R. O. B. (1999). A comparison of specific leaf area, chemical composition and leaf construction costs of field plants from 15 habitats differing in productivity. New Phytol. 143, 163-176. doi: $10.1046 / j .1469-8137.1999 .00428 . x$

Ramus, J. (1978). Seaweed anatomy and photosynthetic performance: the ecological significance of light guides, heterogeneous absorption and multiple scatter. J. Phycol. 14, 352-362. doi: 10.1111/j.1529-8817.1978.tb 00312.x

Ramus, J. (1990). A form-function analysis of photon capture for seaweeds. Hydrobiologia 204, 65-71. doi: 10.1007/BF00040216

Ramus, J., Beale, S., and Mauzerall, D. (1976a). Correlation of changes in pigment content with photosynthetic capacity of seaweeds as a function of water depth. Mar. Biol. 37, 231-238. doi: 10.1007/BF00387608

Ramus, J., Beale, S., Mauzerall, D., and Howard, K. (1976b). Changes in photosynthetic pigment concentration in seaweeds as a function of water depth. Mar. Biol. 37, 223-229. doi: 10.1007/BF00387607

Raven, J. A., and Geider, R. J. (2003). "Adaptation, acclimation and regulation in algal photosynthesis," in Photosynthesis in Algae, eds A. W. D. Larkum, S. E. Douglas, and J. A. Raven (Dordrecht: Springer Netherlands), 385-412.

Rodríguez-Román, A., Hernández-Pech, X., Thomé, P. E., Enríquez, S., and Iglesias-Prieto, R. (2006). Photosynthesis and light utilization in the Caribbean coral Montastraea faveolata recovering from a bleaching event. Limnol. Oceanogr. 51, 2702-2710. doi: 10.4319/lo.2006.51.6.2702

Schubert, N., Colombo-Pallota, M. F., and Enríquez, S. (2015). Leaf and canopy scale characterization of the photoprotective response to high-light stress of the seagrass Thalassia testudinum. Limnol. Oceanogr. 60, 286-302. doi: 10.1002/lno.10024

Schubert, N., and García-Mendoza, E. (2008). Photoinhibition in red algal species with different carotenoid profiles. J. Phycol. 44, 1437-1446. doi: $10.1111 / j .1529-8817.2008 .00590 . x$
Schubert, N., García-Mendoza, E., and Enríquez, S. (2011). Is the photoacclimatory response of Rhodophyta conditioned by the species carotenoid profile? Limnol. Oceanogr. 56, 2347-2361. doi: 10.4319/lo.2011.56.6. 2347

Shibata, K. (1959). Spectrophotometry of translucent biological materials: opal glass transmission method. Methods Biochem. Anal. 7, 77-109. doi: $10.1002 / 9780470110232 . c h 3$

Shibata, K. (1969). Pigments and a UV-absorbing substance in corals and a blue-green alga living in the Great Barrier Reef. Plant Cell Physiol. 10, 325-335.

Steller, D., Hernández-Ayón, J., Riosmena-Rodríguez, R., and Cabello-Pasini, A. (2007). Effect of temperature on photosynthesis, growth and calcification rates of the free-living coralline alga Lithophyllum margaritae. Ciencias Mar. 33, 441-456. doi: $10.7773 / \mathrm{cm} . v 33 i 4.1255$

Steller, D. L., and Foster, M. S. (1995). Environmental factors influencing distribution and morphology of rhodoliths in Bahía Concepción, B.C.S., México. J. Exp. Mar. Biol. Ecol. 194, 201-212. doi: 10.1016/0022-0981(95)00086-0

Steller, D. L., Riosmena-Rodríguez, R., Foster, M. S., and Roberts, C. A. (2003). Rhodolith bed diversity in the Gulf of California: the importance of rhodolith structure and consequences of disturbance. Aquat. Conserv. Mar. Freshw. Ecosyst. 13, S5-S20. doi: 10.1002/aqc.564

Steneck, R., and Dethier, M. (1994). A functional group approach to the structure of algal-dominated communities. Oikos 69, 476-498. doi: 10.2307/35 45860

Steneck, R. S. (1986). The ecology of coralline algal crusts: convergent patterns and adaptative strategies. Annu. Rev. Ecol. Syst. 17, 273-303. doi: 10.1146/annurev.es.17.110186.001421

Steneck, R. S., Hacker, S. D., and Dethier, M. N. (1991). Mechanisms of competitive dominance between crustose coralline algae: an herbivoremediated competitive reversal. Ecology 72, 938-950. doi: 10.2307/19 40595

Vadas, R. L., and Steneck, R. S. (1988). Zonation of deep water benthic algae in the Gulf of Maine. J. Phycol. 24, 338-346. doi: 10.1111/j.1529-8817.1988. tb04476.x

Vásquez-Elizondo, R. M., and Enríquez, S. (2016). Coralline algal physiology is more adversely affected by elevated temperature than reduced $\mathrm{pH}$. Sci. Rep. 6:19030. doi: 10.1038/srep19030

Vásquez-Elizondo, R. M., Legaria-Moreno, L., Pérez-Castro, M. Á., Krämer, W. E., Scheufen, T., Iglesias-Prieto, R., et al. (2017). Absorptance determinations on multicellular tissues. Photosyn. Res. 132, 311-324. doi: 10.1007/s11120-017-0395-6

Vile, D., Garnier, É., Shipley, B., Laurent, G., Navas, M.-L., Roumet, C., et al. (2005). Specific leaf area and dry matter content estimate thickness in laminar leaves. Ann. Bot. 96, 1129-1136. doi: 10.1093/aob/mci264

Vogelmann, T. C., and Björn, L. O. (1984). Measurement of light gradients and spectral regime in plant tissue with a fiber optic probe. Physiol. Plant. 60, 361-368. doi: 10.1111/j.1399-3054.1984.tb 06076.x

Vogelmann, T. C., Bornman, J. F., and Josserand, S. (1989). Photosynthetic light gradients and spectral regime within leaves of Medicago sativa. Phil. Trans. $R$. Soc. Lond. B 323, 411-421. doi: 10.1098/rstb.1989.0020

Vogelmann, T. C., Knapp, A. K., McClean, T. M., and Smith, W. K. (1988). Measurements of light within thin plant tissues with fiber optic microprobes. Physiol. Plant. 72, 623-630. doi: 10.1111/j.1399-3054.1988. tb09173.x

Vogelmann, T. C., Nishio, J. N., and Smith, W. K. (1996). Leaves as light capture: light propagation and gradients of carbon fixation within leaves. Trends Plant Sci. 1, 65-70. doi: 10.1016/S1360-1385(96)80031-8

Wangpraseurt, D., Wentzel, C., Jacques, S. L., Wagner, M., and Kühl, M. (2017). In vivo imaging of coral tissue and skeleton with optical coherence tomography. J. R. Soc. Interface 14:20161003. doi: 10.1098/rsif.20 16.1003

Warner, M. E., Fitt, W. K., and Schmidt, G. W. (1996). The effects of elevated temperature on the photosynthetic efficiency of zooxanthellae in hospite from four different species of reef coral: a novel approach. Plant Cell Environ. 19, 291-299. doi: 10.1111/j.1365-3040.1996. tb00251.x 
Watson, D. J. (1947). Comparative physiological studies in the growth of field crops. I. Variation in net assimilation rate and leaf area between species and varieties, and within and between years. Ann. Bot. 11, 41-76. doi: 10.1093/oxfordjournals.aob.a083148

Williams, E. A., Craigie, A., Yeates, A., and Degnan, S. M. (2008). Articulated coralline algae of the genus Amphiroa are highly effective natural inducers of settlement in the tropical abalone Haliotis asinina. Biol. Bull. 215, 98-107. doi: $10.2307 / 25470687$

Witkowski, E. T. F., and Lamont, B. B. (1991). Leaf specific mass confounds leaf density and thickness. Oecologia 88, 486-493. doi: 10.1007/BF00317710
Conflict of Interest Statement: The authors declare that the research was conducted in the absence of any commercial or financial relationships that could be construed as a potential conflict of interest.

Copyright (C) 2017 Vásquez-Elizondo and Enríquez. This is an open-access article distributed under the terms of the Creative Commons Attribution License (CC BY). The use, distribution or reproduction in other forums is permitted, provided the original author(s) or licensor are credited and that the original publication in this journal is cited, in accordance with accepted academic practice. No use, distribution or reproduction is permitted which does not comply with these terms. 